\title{
PERSISTENCY OF USE OF BOROBUDUR-PRAMBANAN- SEWU ARCHITECTURE (JAWA ERA CENTRAL CLASS) ON BAYON TEMPLE IN KAMBOJA
}

\author{
${ }^{1}$ Nathanael Widyargo. ${ }^{2}$ Dr. Rahadhian Prajudi Herwindo, ST., MT. \\ ${ }^{1}$ Student in the Bachelor's (S-1) Study Program in Architecture \\ at Parahyangan Catholic University \\ ${ }^{2}$ Senior lecturer in the Bachelor's (S-1) Study Program in Architecture \\ at Parahyangan Catholic University
}

\begin{abstract}
Indonesia was in its heyday back then In the time of middle classic era of Hindu and Buddha. It is proved by many construction of big Temple such as Borobudur, Prambanan, and Sewu Temple. In Angkor Kingdom which was younger age was found alleged resemblance to the figure of Angkor temple and Prambanan Borobudur, and Sewu temple. It is also supported by the fact that in the 8th century, King Jayawarman II who built Angkor, returned from Java.The Cambodian temple research object this time is Bayon Temple which is the last civilization of Angkor Kingdom with Prambanan, Borobudur and Sewu temples as a comparative object that represents Middle Classic era of the Javanese temple architecture. The purpose of this research is to know the persistence of architectural elements (massing, plan, figure, and ornamentation) of Borobudur, Sewu and Prambanan temple (Javanese temple of Middle Classic era) at Bayon temple viewed from similarities and differences of these elements.

The research method used in this research is semiquantitative-qualitative method by observing, collecting temple data of research object, then linking data with related theory so that it becomes processed data. Data that have been processed with the theory of each temple then compared each other to get a descriptive analysis of the similarities and differences of its elements. That data was recalculated then to find the amount of similarities of the study object with the object of comparison can be found. From the analysis can be concluded that at Bayon temple there are similarities of element found with Javanese Middle Classic era of architecture, but similarities are only found on the principle of designing the mass, plan, and the figure only, while in ornaments there were found ornaments with the same type exist but not similar or not in the same place.
\end{abstract}

Key Words: persistent, comparation, essential elements of the temple, Javanese Middle Classic era of Architecture, Bayon Temple, acculturation.

\section{PERSISTENSI PENGGUNAAN UNSUR-UNSUR ARSITEKTUR CANDI BOROBUDUR-PRAMBANAN-SEWU (JAWA ERA KLASIK TENGAH) PADA CANDI BAYON DI KAMBOJA}

\author{
${ }^{1}$ Nathanael Widyargo. ${ }^{2}$ Dr. Rahadhian Prajudi Herwindo, ST., MT. \\ ${ }^{1}$ Mahasiswi S1 Program Studi Arsitektur Universitas Katolik Parahyangan \\ 2 Dosen Pembimbing S1 Program Studi Arsitektur Universitas Katolik Parahyangan
}

\begin{abstract}
Abstrak- Indonesia mengalami masa kejayaan arsitektur pada zaman kerajaan Hindu-Buddha. Terbukti dari dibangunnya banyak candi-candi besar terutama di Pulau Jawa seperti Borobudur, Prambanan, dan Sewu. Angkor yang berusia lebih muda usianya ditemukan dugaan kemiripan sosok pada candi Angkor dan candi Prambanan, Borobudur, dan Sewu. Hal itu juga didukung dengan fakta bahwa pada abad ke-8, Raja Jayawarman II yang membangun Angkor, kembali dari Pulau Jawa. Objek studi candi Kamboja yang diteliti kali ini adalah Candi Bayon yang merupakan peradaban terkahir kerajaan Angkor serta Candi Prambanan, Borobudur, dan Sewu sebagai objek pembanding yang mewakili Candi Jawa era Klasik Tengah. Tujuan dari penelitian ini adalah untuk mengetahui persistensi penggunaan unsur-unsur arsitektur (tata massa, denah, sosok,
\end{abstract}

\footnotetext{
${ }^{1}$ Corresponding Author: nwidyargo@gmail.com
} 
dan ornamentasi) Candi Borobudur, Sewu, dan Prambanan (Candi Jawa era Klasik Tengah) pada Candi Bayon ditinjau dari persamaan dan perbedaan unsur-unsur tersebut.

Metode penelitian yang digunakan pada penelitian ini adalah metode kualitatif semi kuantitatif dengan mengobservasi, mengumpulkan data candi objek penelitian, kemudian mengaitkan data dengan teori yang berhubungan sehingga menjadi data terolah. Dari analisa tersebut dapat ditarik kesimpulan bahwa pada Candi Bayon terdapat kesamaan unsur yang ditemukan dengan candi Jawa era Klasik Tengah, namun keserupaan hanya ditemukan pada prinsip perancangan tata massa, denah, dan sosoknya saja, sedangkan pada ornamen ditemukan ornamen yang jenisnya sama ada namun tidak serupa atau tidak berada di tempat yang sama. Hal tersebut diduga akibat adanya akulturasi budaya luar dan transformasi budaya oleh kejeniusan lokal masyarakat Kamboja.

Kata Kunci: persistensi, komparasi, unsur penting candi, Candi Jawa era Klasik Tengah, Candi Bayon, akulturasi.

\section{PENDAHULUAN}

Ditemukan dugaan kemiripan candi Kamboja yang lebih muda usianya dengan candi Jawa era Klasik tengah yang kala itu sedang berjaya di bidang Arsitektur dan diperkuat dengan kembalinya Jayawarman 2 dari Jawa pada abad ke-8 dan membangun kerajaan Angkor. Sekian lama Angkor berkembang akhirnya sampai pada peradaban akhirnya, yaitu era Bayon.

Pembangunan bangunan kuil di Angkor semasa gaya Bayon diduga memiliki representasi candi Jawa didalamnya. Melalui penelitian ini, ingin mengetahui apakah masih terdapat persistensi unsur-unsur candi Jawa era Klasik Tengah pada candi Bayon ditinjau dari persamaan dan perbedaan pada tata massa, denah, sosok dan ornamen antara candi Bayon dengan candi Jawa era Klasik Tengah. Objek candi yang digunakan adalah candi-candi yang memiliki kriteria Candi utama yang berkonsep Gunung, Candi yang mewakili zamannya dan Candi yang relatif utuh pada Periode Jawa era Klasik Tengah dan era Bayon sehingga dipilih Candi Borobudur, Prambanan, Sewu, dan Bayon sebagai objek studi.

Metode penelitian yang dilakukan adalah metode penelitian kualitatif semi kuantitatif. Penelitian ini dilakukan dengan mendatangi dan mengobservasi secara mendalam unsurunsur candi sebagai objek studi, mengaitkan dengan teori yang ada, kemudian mengkomparasi unsur-unsur objek-objek penelitian tersebut.

Dari hasil komparasi unsur-unsur candi dan elemennya tersebut, akan muncul pernyataan kualitatif berupa Tidak Ada, Tidak Serupa, dan Serupa. (1) Tidak Ada. Tidak terdapat elemen pada candi rujukan terhadap candi objek studi yang dapat dibandingkan baik secara jenis, fungsi maupun rupa. (2) Tidak Serupa. Terdapat elemen pada candi rujukan terhadap candi objek studi yang dapat dibandingkan baik secara jenis maupun fungsi dengan rupa berbeda. (3) Serupa. Terdapat elemen pada candi rujukan terhadap candi objek studi yang dapat dibandingkan baik secara jenis maupun fungsi dengan rupa sama.

\section{TEORI CANDI}

\subsection{TEORI CANDI ERA KLASIK TENGAH}

Menurut Prajudi (2011), untuk menganalisis sebuah candi dibutuhkan pengetahuan mengenai unsur-unsur penting dari tipe morfologi, yaitu perletakkan- tata masa, denah, dan sosok.

\section{Tata Massa}

Secara garis besar dapat terbagi menjadi tipe tunggal, berkelompok, berkelompok memusat, dan berjenjang ke belakang yang tersusun dalam kelompok kecil ataupun besar. 


\section{Denah}

Pengembangan denah menjadi bentuk cruciform.
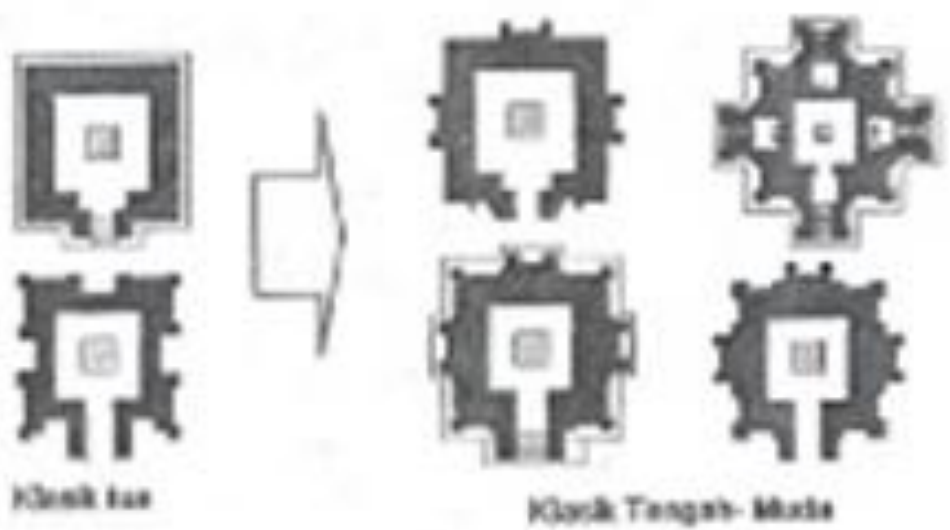

Figur 1. Denah Cruciform Candi

\section{Sosok}

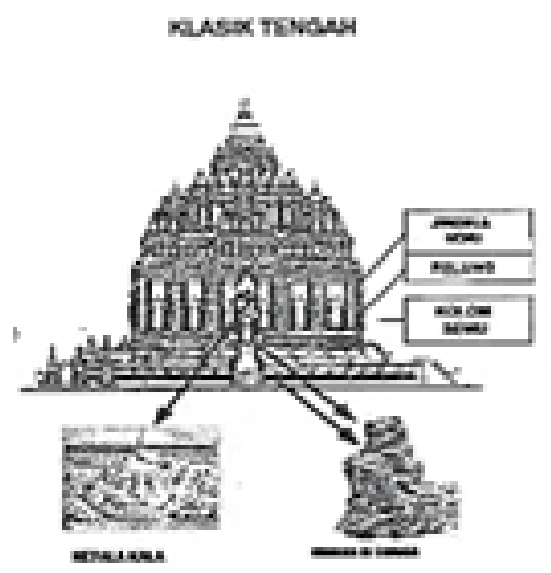

Figur 2. Sosok Candi Jawa era Klasik Tengah

Merupakan pengembangan bentuk sederhana candi Klasik Tua menjadi lebih kompleks. Selain didominasi oleh bentuk menara, ditemukan juga candi dengan bentuk pertirtaan, gapura, serta bangunan berundak (Borobudur). Candi Prambanan dianggap memiliki karakteristik pengolahan yang istimewa sehingga hasilnya terlihat berbeda dengan candi-candi lainya.

(1) Unsur-Unsur Kuat dalam Desain Arsitektur Candi Jawa Klasik Tengah

Wujud tersebut berupa elemen dan ornamen. Berikut adalah pemaparan ornamen candi menurut Prajudi (2011): (1) Profil moulding, (2) Kepala Kala, (3) Simbar (Antefix), (4) Atap bersusun-susun dan mahkota (amalaka, ratna, stupa, kubus pejal, dan meru), (5) Pengolahan Entrance, Pintu, Jendela, relung (non kurva dan kurva), (6) Pengolahan tangga (lidah, Makara), dan (7) Ragam hias motif geometrik kartesian, garis, frame, sulur-suluran, dan medallion.

Menurut Prajudi (2011) selain elemen dan ornamen, terdapat beberapa unsur estetika arsitektural kuat yang selalu muncul dalam desainnya, yaitu: (1) Komposisi gemetrik seperti: kartesian-cuciform, (2) Volumetrik dan solid-void dapat membentuk custer, (3) Hirarki image segitiga - efek perspektif, (4) Pembagian tiga, (5) Irama dan perulangan - datum, (6) Kesimetrisan -pusat perhatian- keseimbangan, (7) Mimesis dalam wujud sosok bangunan 
atau ornament, (8) Tekstur membentuk elemen garis dan efek gelap terang, (9) Sumbu (axis) berbentuk llinear atau memusat, dan (10) Proporsi dan skala.

\subsection{TEORI CANDI ANGKOR}

(1) Ciri khas arsitektur candi Angkor

Ciri khas arsitektur Angkor yaitu: penggunaan denah berbentuk Cruciform untuk ruangan utama,penggunaan Galeri konsentrik asimetris pada tatanan candi, selasar beratap, dan menara Quincunx.

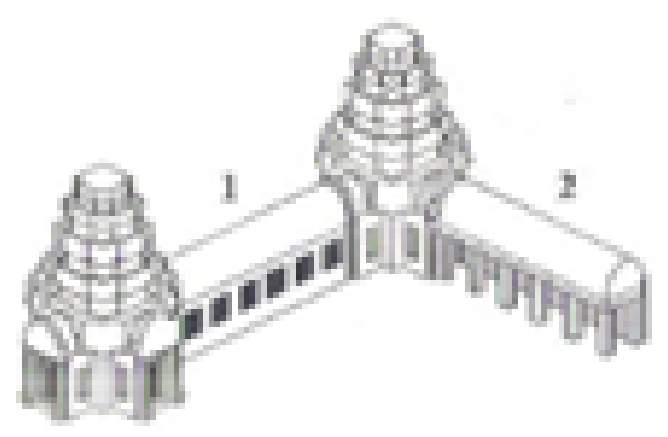

Figur 3. Selasar beratap candi Kamboja Sumber: Focusing on the Angkor Temple The Guidebook, 2012

\section{Quincunx}

Pada candi Angkor ditemukan tatanan yang spesial pada candi utamanya yaitu penataan Quincunx dimana satu menara utama dikelilingi oleh 4 menara sekunder.
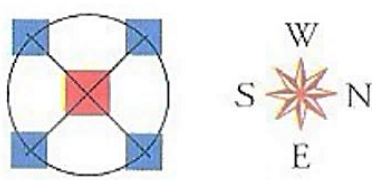

Mountain-Temples

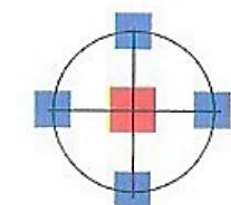

Jayavarman VII
Figur 4. Komparasi Quincunx sebelum dan sesudah raja Jayawarman VII

Sumber: Focusing on the Angkor Temple The Guidebook, 2012

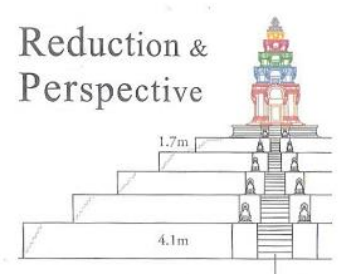

Figur 5. Efek Perspektifis Candi Angkor Sumber: Focusing on the Angkor Temple The Guidebook, 2012

\section{Elemen Pembentuk Kuil}

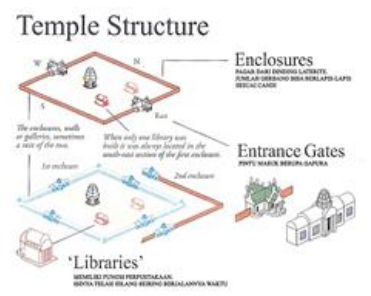

Figur 2. Aksonometri elemen candi Angkor Sumber:Focusing on the Angkor Temple The Guidebook, 2012 


\section{Elemen pintu candi Angkor}
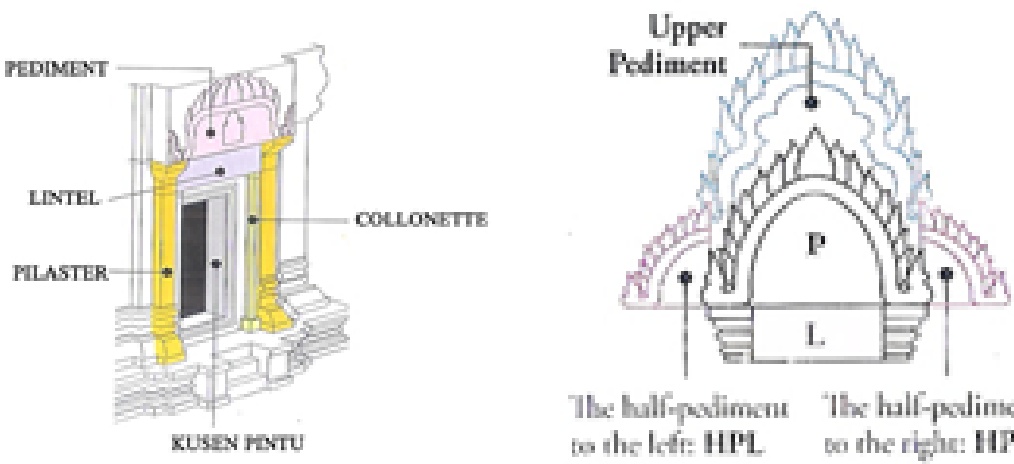

The half-podimcas The half-podimones to the left: HPL to the righe: HPR

Figur 7. Pembagian ornamen pintu candi Angkor

Sumber: Focusing on the Angkor Temple The Guidebook, 2012

\section{KOMPARASI UNSUR}

\subsection{TATA MASSA}

Tabel 1. Komparasi Tata Massa

Sumber Gambar: Pusat Studi Angkor, Balai Penelitian Borobudur, dan Balai Pemugaran Cagar Budaya Yogyakarta, buku Candi Sewu (2007); dengan modifikasi penulis

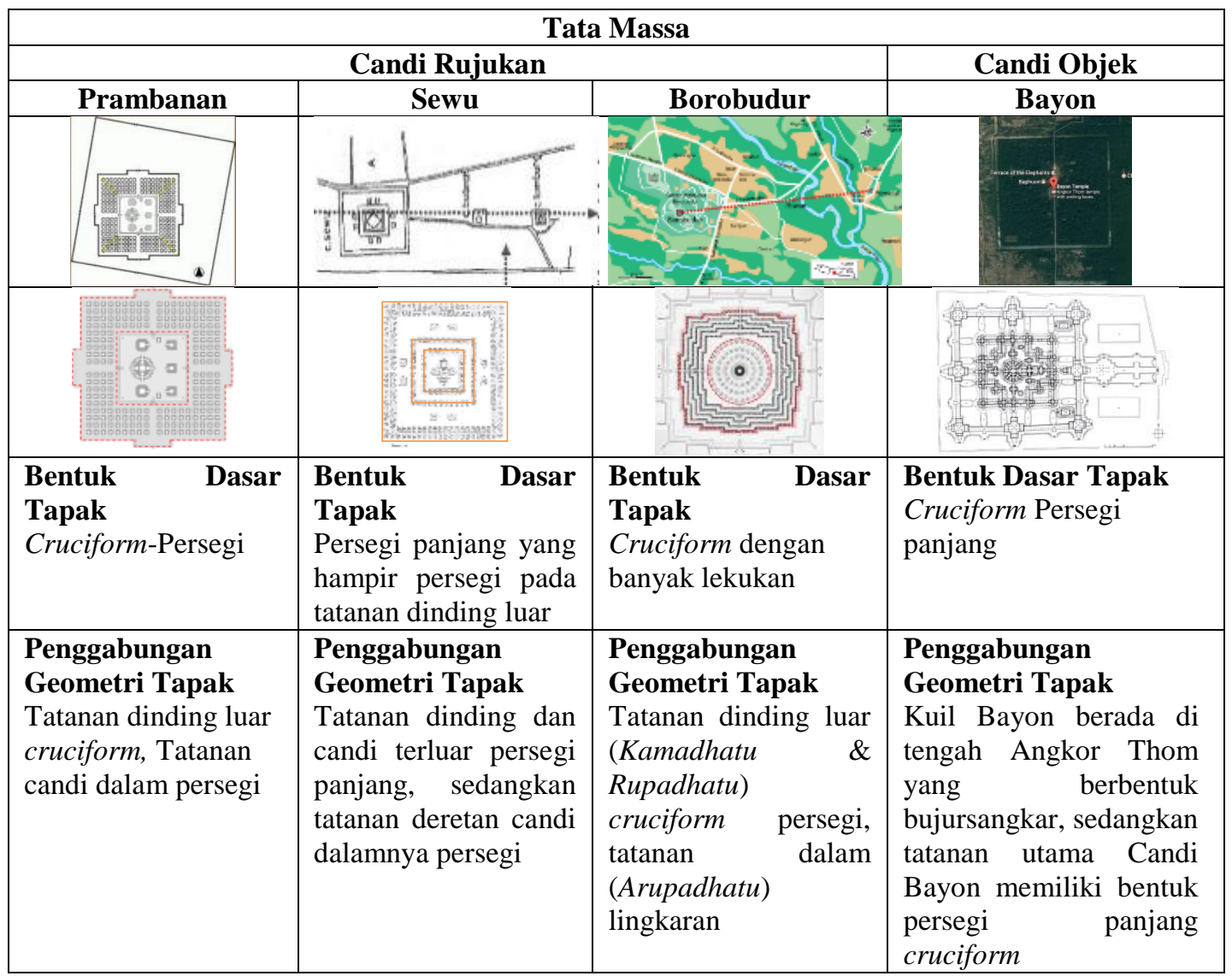




\begin{tabular}{|c|c|c|c|}
\hline \multicolumn{4}{|c|}{ Tata Massa } \\
\hline \multicolumn{3}{|c|}{ Candi Rujukan } & Candi Objek \\
\hline Prambanan & Sewu & Borobudur & Bayon \\
\hline 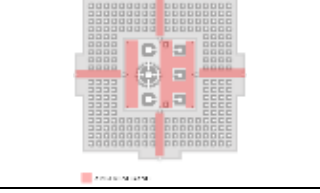 & 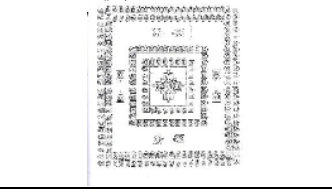 & & 8 \\
\hline $\begin{array}{l}\text { Koridor r yang } \\
\text { Dibentuk Tatanan } \\
\text { Solid Massa } \\
\text { Koridor memiliki } \\
\text { axis ke pusat (candi } \\
\text { utama) }\end{array}$ & $\begin{array}{lr}\text { Koridor } & \text { yang } \\
\text { Dibentuk Tatanan } & \\
\text { Solid Massa } \\
\text { Koridor Mengitari } \\
\text { Bangunan Candi dan } \\
\text { menusuk ke tengah } \\
\text { candi utama }\end{array}$ & $\begin{array}{l}\text { Koridor } \quad \text { yang } \\
\text { Dibentuk Tatanan } \\
\text { Solid Massa } \\
\text { Koridor Mengitari } \\
\text { Stupa Utama }\end{array}$ & $\begin{array}{l}\text { Koridor yang Dibentuk } \\
\text { Tatanan Solid Massa } \\
\text { Pada Bayon memiliki } \\
\text { koridor selasar beratap } \\
\text { mengitari candi utama } \\
\text { dan menusuk ke candi } \\
\text { utama }\end{array}$ \\
\hline $\begin{array}{l}\text { Area Void (Massa } \\
\text { Renggang) } \\
\text { Terdapat ruang } \\
\text { outdoor besar } \\
\text { peralihan ke } \\
\text { candi utama }\end{array}$ & $\begin{array}{l}\text { Area Void (Massa } \\
\text { Renggang) } \\
\text { Terdapat ruang } \\
\text { outdoor besar pada } \\
\text { perlalihan ke area } \\
\text { candi utama, dan } \\
\text { ruang outdoor yang } \\
\text { terbentuk oleh jeda } \\
\text { tatanan candi perwara } \\
\text { yang mengelilingi } \\
\text { candi utama } \\
\end{array}$ & $\begin{array}{lr}\text { Area Void } & \text { (Massa } \\
\text { Renggang) } & \\
\text { Berada pada } & \text { area } \\
\text { peralihan } & \text { bentuk } \\
\text { cruciform } & \text { dan } \\
\text { lingkaran } & \end{array}$ & $\begin{array}{l}\text { Area Void (Massa } \\
\text { Renggang) } \\
\text { Void terbuka terbentuk } \\
\text { oleh dinding luar selasar, } \\
\text { ruang dalam dan massa } \\
\text { tower }\end{array}$ \\
\hline $\begin{array}{l}\text { Jumlah Hirarki } \\
\text { pada Tapak (dibaca } \\
\text { melalui undakan \& } \\
\text { gerbang) } \\
3 \text { buah undakan. } \\
\text { Kelompok candi } \\
\text { utama Prambanan } \\
\text { terletak pada pagar } \\
\text { paling dalam dari } \\
\text { tatanan candi }\end{array}$ & $\begin{array}{lr}\begin{array}{l}\text { Jumlah } \\
\text { (dibaca }\end{array} & \begin{array}{r}\text { Hirarki } \\
\text { melalui } \\
\text { undakan } \\
\text { gerbang) }\end{array} \\
3 \quad \text { dan } \\
\text { Keseluah } & \text { hirarki } \\
\text { berada di } & \text { landasan } \\
\text { batu dimana } & \text { undakan } \\
\text { candi } & \text { utama } \\
\text { merupakan } & \text { yang } \\
\text { tertinggi } & \end{array}$ & $\begin{array}{lr}\begin{array}{l}\text { Jumlah } \\
\text { (dibaca }\end{array} & \begin{array}{r}\text { Hirarki } \\
\text { melalui } \\
\text { undakan } \\
\text { gerbang) }\end{array} \\
3 \quad \text { dan } \\
\text { (Kamadhatu, } & \\
\begin{array}{l}\text { Rupadhatu, } \\
\text { Arupadhatu) }\end{array} & \\
\end{array}$ & $\begin{array}{l}\text { Jumlah Hirarki pada } \\
\text { Tapak (dibaca melalui } \\
\text { undakan \& gerbang) } \\
\text { Terdapat } 3 \text { hirarki utama } \\
\text { yaitu outer gallery, inner } \\
\text { gallery, dan upper } \\
\text { terrace }\end{array}$ \\
\hline $\begin{array}{l}\text { Pemusatan Hirarki } \\
\text { (Semakin Pusat } \\
\text { Semakin Suci) } \\
\text { Candi utama Siwa } \\
\text { tidak berada tepat di } \\
\text { pusat namun berada } \\
\text { di tengah candi } \\
\text { Wisnu dan candi } \\
\text { Brahma }\end{array}$ & $\begin{array}{l}\text { Pemusatan Hirarki } \\
\text { (Semakin Pusat } \\
\text { Semakin Suci) } \\
\text { Candi utama berada } \\
\text { tepat di pusat tatanan } \\
\text { massa }\end{array}$ & $\begin{array}{l}\text { Pemusatan Hirarki } \\
\text { (Semakin Pusat } \\
\text { Semakin Suci) } \\
\text { Candi Stupa utama } \\
\text { berada tepat di pusat } \\
\text { dikelilingi seluruh } \\
\text { massa bangunan }\end{array}$ & $\begin{array}{lr}\begin{array}{l}\text { Pemusatan } \\
\text { (Semakin Hirarki } \\
\text { Semakin Suci) }\end{array} & \begin{array}{r}\text { Pusat } \\
\text { menara utama }\end{array} \\
\text { sebasat } \\
\text { dikelilingi seluruh massa } \\
\text { bangunan }\end{array}$ \\
\hline 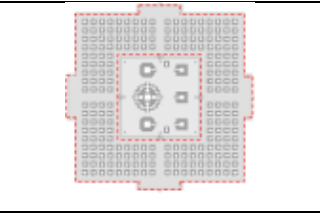 & 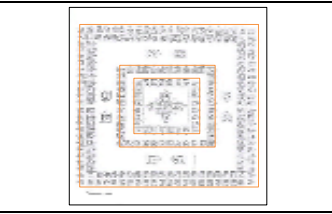 & & if \\
\hline $\begin{array}{ll}\text { Perulangan } & \text { Bentuk } \\
\text { Dasar Geometrik } \\
\text { Pengulangan } & \text { bentuk } \\
\text { geometrik } & \text { persegi } \\
\end{array}$ & $\begin{array}{l}\text { Perulangan Bentuk } \\
\text { Dasar Geometrik } \\
\text { Pengulangan bentuk } \\
\text { geometrik segiempat }\end{array}$ & $\begin{array}{l}\text { Perulangan Bentuk } \\
\text { Dasar Geometrik } \\
\text { Pengulangan bentuk } \\
\text { geometrik cruciform }\end{array}$ & $\begin{array}{l}\text { Perulangan Bentuk } \\
\text { Dasar Geometrik } \\
\text { perulangan bentuk } \\
\text { persegi panjang pada }\end{array}$ \\
\hline
\end{tabular}




\begin{tabular}{|c|c|c|c|}
\hline \multicolumn{4}{|c|}{ Tata Massa } \\
\hline \multicolumn{3}{|c|}{ Candi Rujukan } & Candi Objek \\
\hline Prambanan & Sewu & Borobudur & Bayon \\
\hline $\begin{array}{lr}\text { namun } & \text { tidak } \\
\text { cruciform } & \text { untuk } \\
\text { tatanan massa } & \text { candi } \\
\text { perwara } & \end{array}$ & $\begin{array}{l}\text { untuk tatanan massa } \\
\text { candi perwara }\end{array}$ & $\begin{array}{l}\text { dan lingkaran pada } \\
\text { penataan dinding/ } \\
\text { Pagar dan } \\
\text { penyusunan stupa }\end{array}$ & $\begin{array}{l}\text { pola penataan selasar dan } \\
\text { candi-candi anaknya }\end{array}$ \\
\hline 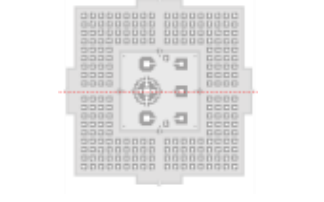 & 1. & & 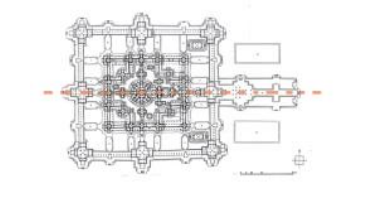 \\
\hline $\begin{array}{l}\text { Sisi Simetri } \\
\text { Timur-Barat }\end{array}$ & $\begin{array}{l}\text { Sisi Simetri } \\
\text { Timur-Barat } \\
\text { Utara-Selatan } \\
\text { Diagonal }\end{array}$ & $\begin{array}{l}\text { Sisi Simetri } \\
\text { Timur-Barat } \\
\text { Utara-Selatan } \\
\text { Diagonal } \\
\end{array}$ & $\begin{array}{l}\text { Sisi Simetri } \\
\text { Timur-Barat }\end{array}$ \\
\hline 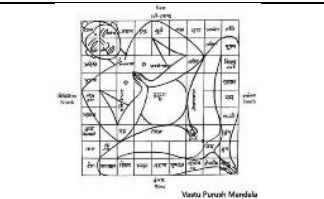 & (atsis & 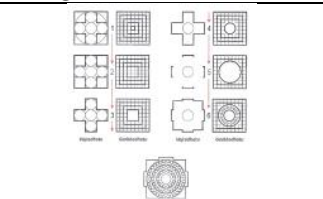 & \\
\hline $\begin{array}{l}\text { Penerapan Bentuk } \\
\text { Denah } \\
\text { Mandala Hindu }\end{array}$ & $\begin{array}{lr}\text { Penerapan Mandala } \\
\text { Tibetan } & \text { Mandala } \\
\text { Buddha dan } & \text { analogi } \\
\text { gunung } & \text { Meru } \\
\text { dikeliligi } & \text { lautan } \\
\text { kosmis } & \text { dan } \\
\text { pegunungan } & \end{array}$ & $\begin{array}{l}\text { Penerapan Mandala } \\
\text { Mandala Buddha } \\
\text { Garbhadhatu dan } \\
\text { Vajradhatu Mandala }\end{array}$ & $\begin{array}{lr}\text { Penerapan } & \text { Mandala } \\
\text { Buddha } & \\
\text { Tibetan } & \text { Mandala } \\
\text { Gunung } & \text { Meru } \\
\text { diwujudkan dengan } \\
\text { menara Quincunx, laut } \\
\text { oleh sungai Angkor } \\
\text { Thom, dan pegunungan } \\
\text { oleh pagar. }\end{array}$ \\
\hline 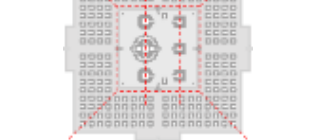 & & $y=$ & \\
\hline $\begin{array}{l}\text { Axis Memusat } \\
\text { Tatanan memusat } \\
\text { candi perwara } \\
\text { terhadap area candi } \\
\text { utama }\end{array}$ & $\begin{array}{l}\text { Axis Memusat } \\
\text { Tatanan memusat } \\
\text { pada Candi utama } \\
\text { yang diletakkan tepat } \\
\text { di tengah-tengah } \\
\text { tatanan. }\end{array}$ & $\begin{array}{l}\text { Axis Memusat } \\
\text { Pada Borobudur } \\
\text { terbentuk axis yang } \\
\text { sangat seimbang } \\
\text { menuju ke tengah- } \\
\text { tengah stupa } \\
\text { utamanya. }\end{array}$ & $\begin{array}{l}\text { Axis Memusat } \\
\text { Tatanan massa memusat } \\
\text { mengelilingi candi utama } \\
\text { sebagai pusat. }\end{array}$ \\
\hline $\begin{array}{l}\text { Axis Linier } \\
\text { Tatanan linier pada } \\
\text { candi wahana dan } \\
\text { tiga candi utama }\end{array}$ & $\begin{array}{l}\text { Axis Linier } \\
\text { Tatanan linier } \\
\text { terhadap Candi } \\
\text { Lumbung dan Bubrah }\end{array}$ & $\begin{array}{l}\text { Axis Linier } \\
\text { Tatanan linier } \\
\text { terhadap Candi } \\
\text { Pawon dan mendut }\end{array}$ & $\begin{array}{l}\text { Axis Linier } \\
\text { Terbentuk dari Denah } \\
\text { berbentuk persegi } \\
\text { panjang, dan terdapat } \\
\text { selasar depan pada tapak. }\end{array}$ \\
\hline
\end{tabular}

\subsection{DENAH}

Terdapat 2 jenis tata ruang yang akan dibahas pada candi Indonesia dan Kamboja, yaitu tata ruang luar dan tata ruang dalam (denah). Pada pembahasan denah ini lebih difokuskan kepada denah dalam bangunan candi dan tata letak pada penataan candi utama bila terdapat beberapa candi utama, yang artinya bukan merupakan kesatuan tatanan ruang yang dibentuk oleh banyak candi. 
Tabel 2. Komparasi Denah

Sumber gambar: Pusat Studi Angkor, Balai Penelitian Borobudur, dan Balai Pemugaran Cagar Budaya Yogyakarta, buku Candi Sewu (2007); dengan modifikasi penulis

\begin{tabular}{|c|c|c|c|}
\hline \multicolumn{4}{|c|}{ Geometrik } \\
\hline \multicolumn{3}{|c|}{ Candi Rujukan } & Candi Objek \\
\hline Prambanan & Sewu & Borobudur & Bayon \\
\hline 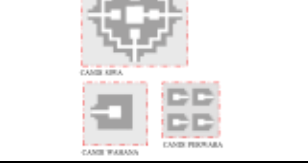 & 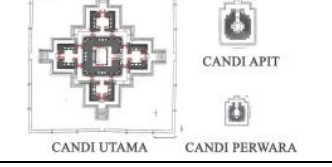 & & 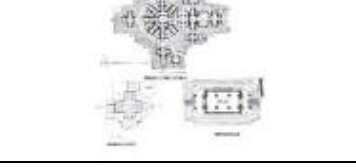 \\
\hline \begin{tabular}{lr}
\multicolumn{2}{l}{ Bentuk Dasar Denah } \\
Bentuk dasar & Candi \\
Utama & adalah \\
cruciform & \\
Sedangkan & candi \\
wahana & dan \\
perwaranya & adalah \\
persegi & dengan \\
pemanjangan & ruang \\
pada sisi pintu & masuk.
\end{tabular} & $\begin{array}{lr}\text { Bentuk } & \text { Dasar } \\
\text { Denah } & \\
\text { Bentukan dasar denah } \\
\text { candi } & \text { utama } \\
\text { cruciform. } & \\
\text { Pada Candi } & \text { apit dan } \\
\text { candi r perwara } \\
\text { cruciform rengan } \\
\text { pemanjangan } & \text { ruang } \\
\text { pada sisi pintu masuk. }\end{array}$ & $\begin{array}{l}\text { Bentuk Dasar } \\
\text { Denah } \\
\text { Bentuk dasar stupa } \\
\text { utama Lingkaran }\end{array}$ & $\begin{array}{l}\text { Bentuk Dasar Denah } \\
\text { Bentuk dasar Candi } \\
\text { Utama (Prasat) adalah } \\
\text { Lingkaran dengan teras } \\
\text { cruciform } \\
\text { Sedangkan candi anak, } \\
\text { inner court dan } \\
\text { perpusatakaan } \\
\text { berbentuk cruciform. }\end{array}$ \\
\hline $\begin{array}{l}\text { Penggabungan } \\
\text { Geometri Denah } \\
\text { Pada Candi Utama } \\
\text { denah luarnya } \\
\text { cruciform, denah } \\
\text { dalamnya bujur } \\
\text { sangkar, Pada Candi } \\
\text { Wahana dan } \\
\text { Perwara denah luar } \\
\text { dan dalam berbentuk } \\
\text { persegi }\end{array}$ & $\begin{array}{l}\text { Penggabungan } \\
\text { Geometri Denah } \\
\text { Ruang dalam pada } \\
\text { candi utama } \\
\text { berbentuk persegi } \\
\text { sedangkan sisi } \\
\text { luarnya cruciform }\end{array}$ & $\begin{array}{l}\text { Penggabungan } \\
\text { Geometri Denah } \\
\text { Denah stupa dan } \\
\text { sekelilingnya } \\
\text { berbentuk lingkaran }\end{array}$ & $\begin{array}{l}\text { Penggabungan } \\
\text { Geometri Denah } \\
\text { Penggabungan bentuk } \\
\text { persegi panjang, } \\
\text { cruciform, dan } \\
\text { lingkaran pada denah }\end{array}$ \\
\hline 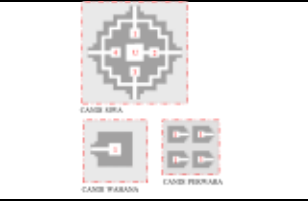 & 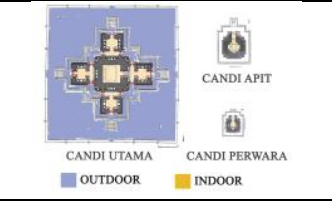 & 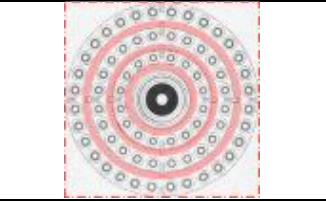 & \\
\hline $\begin{array}{l}\text { Area Aktivitas } \\
\text { Area aktivitas Candi } \\
\text { Sewu dilakukan di } \\
\text { dalam (ruang candi) } \\
\text { dan di luar ruangan } \\
\text { (ruang void outdoor) }\end{array}$ & $\begin{array}{l}\text { Area Aktivitas } \\
\text { Area aktivitas Candi } \\
\text { Sewu dilakukan di } \\
\text { dalam (ruang candi) } \\
\text { dan di luar ruangan } \\
\text { (ruang void outdoor) }\end{array}$ & $\begin{array}{l}\text { Area Aktivitas } \\
\text { Seluruh aktivitas } \\
\text { berada di luar stupa, } \\
\text { ruang dalam stupa } \\
\text { tidak dapat diakses }\end{array}$ & $\begin{array}{l}\text { Area Aktivitas } \\
\text { Aktifitas pada Candi } \\
\text { Bayon dilakukan di } \\
\text { dalam dan luar ruangan. } \\
\text { Ruang dalam pada } \\
\text { menara wajah memiliki } \\
\text { patung pemujaan } \\
\text { didalamnya }\end{array}$ \\
\hline \begin{tabular}{lr}
\multicolumn{3}{l}{ Ruang void Candi } \\
Ruang void yang \\
terbentuk pada \\
candi-candi \\
prambanan \\
umumnya ruang \\
tunggal berbentuk \\
bujur sangkar. \\
Hanya pada candi \\
Siwa (terbesar) \\
memiliki 4 ruang \\
palsu yang 3 \\
diantaranya buntu.
\end{tabular} & $\begin{array}{l}\text { Ruang void Candi } \\
\text { Utama } \\
\text { Ruang dalam candi } \\
\text { utama: } 1 \text { ruang utama, } \\
\text { dan } 4 \text { ruang pada } \\
\text { sumbu kardinal mata } \\
\text { angin. Ruang saling } \\
\text { terhubung oleh } \\
\text { koridor. }\end{array}$ & $\begin{array}{l}\text { Ruang void Candi } \\
\text { Utama } \\
\text { Berbentuk lingkaran } \\
\text { tanpa bukaan }\end{array}$ & $\begin{array}{l}\text { Ruang void Candi } \\
\text { Utama (Prasat) } \\
\text { Ruang utama Prasat } \\
\text { dikelilingi secara radial } \\
\text { oleh } 8 \text { ruang pada arah } \\
\text { mata angin. ruang } \\
\text { depan menghadap timur } \\
\text { mengalami ekstensi. } \\
\text { Kemudian diapit lagi } \\
\text { oleh } 4 \text { ruang utama } \\
\text { satelit pada keempat } \\
\text { sumbu cardinal mata } \\
\text { angin. }\end{array}$ \\
\hline
\end{tabular}




\begin{tabular}{|c|c|c|c|}
\hline \multicolumn{4}{|c|}{ Geometrik } \\
\hline \multicolumn{3}{|c|}{ Candi Rujukan } & Candi Objek \\
\hline Prambanan & Sewu & Borobudur & Bayon \\
\hline 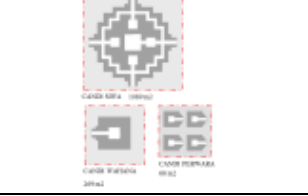 & $\underset{\text { CANDI UTAMA }}{\infty}$ & & 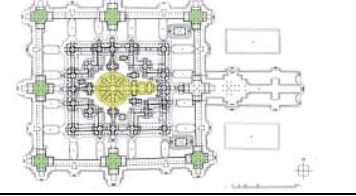 \\
\hline $\begin{array}{l}\text { Perbandingan } \\
\text { ukuran candi } \\
\text { terhadap hirarki } \\
\text { Candi Utama Siwa > } \\
\text { Candi Wisnu \& } \\
\text { Brahma > Candi } \\
\text { Perwara dan candi } \\
\text { lainnya }\end{array}$ & $\begin{array}{l}\text { Perbandingan } \\
\text { ukuran candi } \\
\text { terhadap hirarki } \\
\text { Candi Utama > Candi } \\
\text { Apit > Candi Perwara } \\
\text {. }\end{array}$ & $\begin{array}{l}\text { Perbandingan } \\
\text { ukuran candi } \\
\text { terhadap hirarki } \\
\text { Stupa utama > stupa } \\
\text { anak }\end{array}$ & $\begin{array}{l}\text { Perbandingan ukuran } \\
\text { candi terhadap } \\
\text { hirarki } \\
\text { Denah candi Prasat > } \\
\text { denah candi anak }\end{array}$ \\
\hline $\begin{array}{l}\text { Pemusatan Hirarki } \\
\text { (semakin pusat } \\
\text { semakin suci) } \\
\text { terdapat } 4 \text { ruang } \\
\text { kecil dan } 1 \text { ruang } \\
\text { utama penyembahan } \\
\text { Dewa Siwa pada } \\
\text { Candi Utama Siwa }\end{array}$ & $\begin{array}{l}\text { Pemusatan Hirarki } \\
\text { (semakin pusat } \\
\text { semakin suci) } \\
\text { terdapat } 4 \text { ruang kecil } \\
\text { mengelilingi 1 ruang } \\
\text { utama penyembahan }\end{array}$ & $\begin{array}{l}\begin{array}{l}\text { Pemusatan Hirarki } \\
\text { (semakin pusat }\end{array} \\
\text { semakin suci) } \\
\text { Stupa Utama berada } \\
\text { di tengah-tengah } \\
\text { denah Borobudur. }\end{array}$ & $\begin{array}{lr}\begin{array}{l}\text { Pemusatan } \\
\text { (semakin }\end{array} & \begin{array}{r}\text { Hirarki } \\
\text { pusat }\end{array} \\
\text { semakin suci) } & \\
\text { Ruang utama berada } \\
\text { tepat di pusat dikelilingi } \\
8 \text { ruang-ruang lainnya. }\end{array}$ \\
\hline 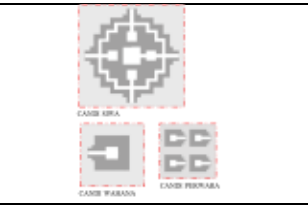 & $\underset{\text { CANDI UTAMA }}{0}$ & 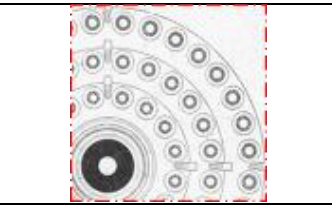 & 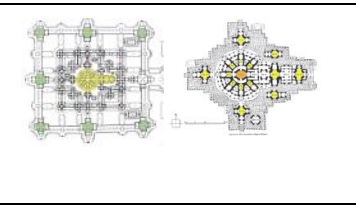 \\
\hline $\begin{array}{l}\text { Perulangan bentuk } \\
\text { denah } \\
\text { Bentuk denah candi } \\
\text { utama Siwa tidak } \\
\text { terulang pada candi } \\
\text { lain, namun denah } \\
\text { candi wahana dan } \\
\text { perwara terulang } \\
\text { sesuai dengan } \\
\text { jumlah candi yang } \\
\text { ada }\end{array}$ & $\begin{array}{l}\text { Perulangan bentuk } \\
\text { denah } \\
\text { Bentuk ruang yang } \\
\text { mengapit candi utama } \\
\text { mengalami } \\
\text { perulangan pada } \\
\text { keempat sisi kardinal } \\
\text { mata angin } \\
\text { Bentuk denah candi } \\
\text { Apit dan candi } \\
\text { Perwara diulang } \\
\text { sesuai dengan jumlah } \\
\text { candi yang ada. }\end{array}$ & $\begin{array}{l}\text { Perulangan bentuk } \\
\text { denah } \\
\text { Bentuk denah stupa } \\
\text { (lingkaran) diulang } \\
\text { pada stupa-stupa yang } \\
\text { lebih kecil. }\end{array}$ & $\begin{array}{lr}\begin{array}{l}\text { Perulangan } \\
\text { denah }\end{array} & \text { bentuk } \\
\text { Perulangan } & \text { bentuk } \\
\text { ruang tower } & \text { sudut } \\
\text { Perulangan } & \text { bentuk } \\
\text { ruang yang mengelingi } \\
\text { ruang utama Prasat }\end{array}$ \\
\hline 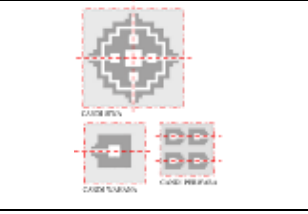 & 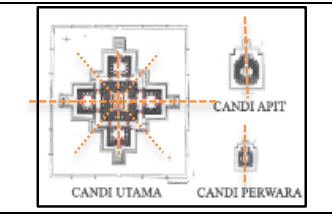 & 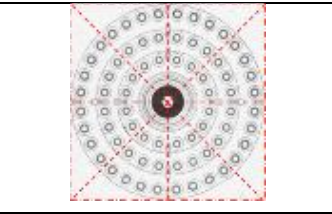 & 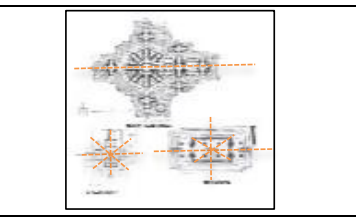 \\
\hline $\begin{array}{l}\text { Sisi Simetri } \\
\text { Simetri pada } \\
\text { keempat sisi } \\
\text { cruciform, namun } \\
\text { akses pintu ke ruang } \\
\text { tengah hanya ada } \\
\text { pada sisi timur } \\
\text { Candi perwara } \\
\text { simetris bila dibelah } \\
\text { pada sumbu pintu } \\
\text { masuk. }\end{array}$ & $\begin{array}{l}\text { Sisi Simetri } \\
\text { Candi Utama } \\
\text { pada secara } \\
\text { horizontris } \\
\text { diagonal. } \\
\text { Candi Apit dal } \\
\text { perwara simetris bila } \\
\text { dibelah pada sumbu } \\
\text { pintu masuk. }\end{array}$ & $\begin{array}{l}\text { Sisi Simetri } \\
\text { Berbentuk lingkaran } \\
\text { sehingga simetri pada } \\
\text { semua bagian }\end{array}$ & $\begin{array}{l}\text { Sisi Simetri } \\
\text { Denah Prasat pada } \\
\text { Bayon simetris jika } \\
\text { dibelah dengan } \\
\text { orientasi timur barat } \\
\text { Denah menara candi } \\
\text { anak dan perpustakaan } \\
\text { simetris secara vertikal } \\
\text { horizontal dan diagonal. }\end{array}$ \\
\hline
\end{tabular}




\begin{tabular}{|c|c|c|c|}
\hline \multicolumn{4}{|c|}{ Geometrik } \\
\hline \multicolumn{3}{|c|}{ Candi Rujukan } & Candi Objek \\
\hline Prambanan & Sewu & Borobudur & Bayon \\
\hline $1 \sqrt{1} \sqrt{4}$ & 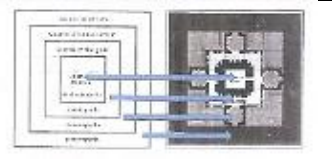 & (a) & 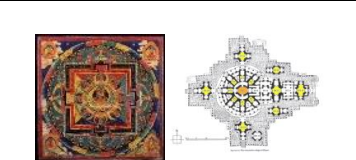 \\
\hline $\begin{array}{l}\text { Penerapan Bentuk } \\
\text { Denah } \\
\text { Pada candi Siwa } \\
\text { mewujudkan bentuk } \\
\text { crusiform sebagai } \\
\text { simbolisasi } \\
\text { bangunan pemujaan, } \\
\text { pada candi wahana } \\
\text { denah } \\
\text { memperlihatkan } \\
\text { bentuk yoni. }\end{array}$ & $\begin{array}{l}\text { Penerapan } \\
\text { Denah } \\
\text { Penerapan vajradhatu } \\
\text { mandala pada } \\
\text { pembentukan denah } \\
\text { candi utama Sewu. } \\
\text { Bentuk cruciform } \\
\text { pada denah juga } \\
\text { merepresentasikan } \\
\text { bangunan suci } \\
\text { pemujaan. }\end{array}$ & $\begin{array}{l}\text { Penerapan Bentuk } \\
\text { Denah } \\
\text { Denah } \\
\text { keseluruhannya } \\
\text { merupakan } \\
\text { penggabungan } \\
\text { vajradhatu \& } \\
\text { garbhadhatu mandala } \\
\text { dengan stupa utama } \\
\text { di pusat berbentuk } \\
\text { lingkaran seperti pada } \\
\text { gambar mandala. }\end{array}$ & $\begin{array}{l}\text { Penerapan } \\
\text { Denah } \\
\text { Denah mentuk } \\
\text { konsep mapkan } \\
\text { Buddha mandala } \\
\text { terdapat bentukan ruang } \\
\text { utama lingkaran yang } \\
\text { dikelilingi ruang-ruang } \\
\text { kecil lainnya searah } \\
\text { dengan penjuru mata } \\
\text { angin. } \\
\text { Pada Perpustakaan dan } \\
\text { menara-menara kecil } \\
\text { menggunakan bentukan } \\
\text { cruciform yang } \\
\text { merupakan modifikasi } \\
\text { segiempat dari mandala } \\
\end{array}$ \\
\hline 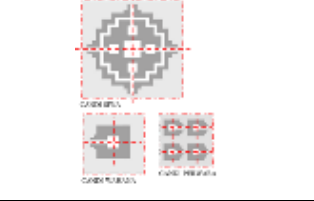 & 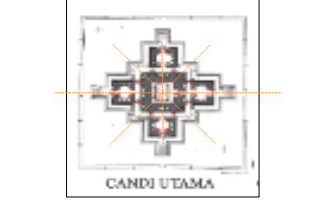 & 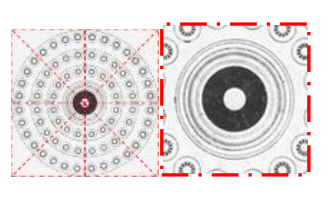 & 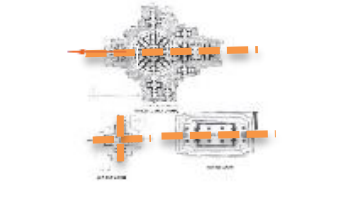 \\
\hline $\begin{array}{l}\text { Tipe Axis } \\
\text { Memusat sedikit } \\
\text { linear, posisi } \\
\text { berada di pung } \\
\text { bangunan } \\
\text { namun dengan pintu } \\
\text { masuk hanya } \\
\text { sisi (linier) }\end{array}$ & $\begin{array}{l}\text { Tipe Axis } \\
\text { Memusat Pada Ruang } \\
\text { Utama }\end{array}$ & $\begin{array}{l}\text { Tipe Axis } \\
\text { Memusat ke } \\
\text { lingkaran } \\
\text { utama. }\end{array}$ & $\begin{array}{l}\text { Tipe Axis } \\
\text { Memusat ke ruang } \\
\text { utama } \\
\text { Linear karena ada ruang } \\
\text { depan. }\end{array}$ \\
\hline
\end{tabular}

\subsection{SOSOK}

Tabel 3. Komparasi Sosok

Sumber gambar: Pusat Studi Angkor, Balai Penelitian Borobudur, dan Balai Pemugaran Cagar Budaya Yogyakarta, buku Candi Sewu (2007); dengan modifikasi penuli

\begin{tabular}{|c|c|c|c|}
\hline \multicolumn{4}{|c|}{ Geometrik } \\
\hline & Candi Rujukan & & Candi Objek \\
\hline Prambanan & Sewu & Borobudur & Bayon \\
\hline $\begin{array}{l}\text { Keserupaan dengan } \\
\text { bentuk dasar } \\
\text { Lebih merepresentasikan } \\
\text { bentuk dasar segitiga } \\
\text { pada sosok keseluruhan } \\
\text { dan sosok candi tunggal. }\end{array}$ & $\begin{array}{l}\text { Keserupaan dengan } \\
\text { bentuk dasar } \\
\text { Terbentuk kurva } \\
\text { seperi bentukan stupa } \\
\text { pada sosok candi }\end{array}$ & \begin{tabular}{lr} 
Keserupaan dengan \\
bentuk dasar \\
Terbentuk & sosok \\
segitiga pada & sosok \\
keseluruhan & bila \\
menara pada & stupa \\
\multicolumn{2}{l}{ utama masih ada. }
\end{tabular} & \begin{tabular}{lr}
\multicolumn{2}{l}{ Keserupaan } \\
dengan & bentuk \\
dasar & \\
Siluet & sosok \\
bangunan & \\
keseluruhan & \\
menyerupai & bentuk
\end{tabular} \\
\hline
\end{tabular}




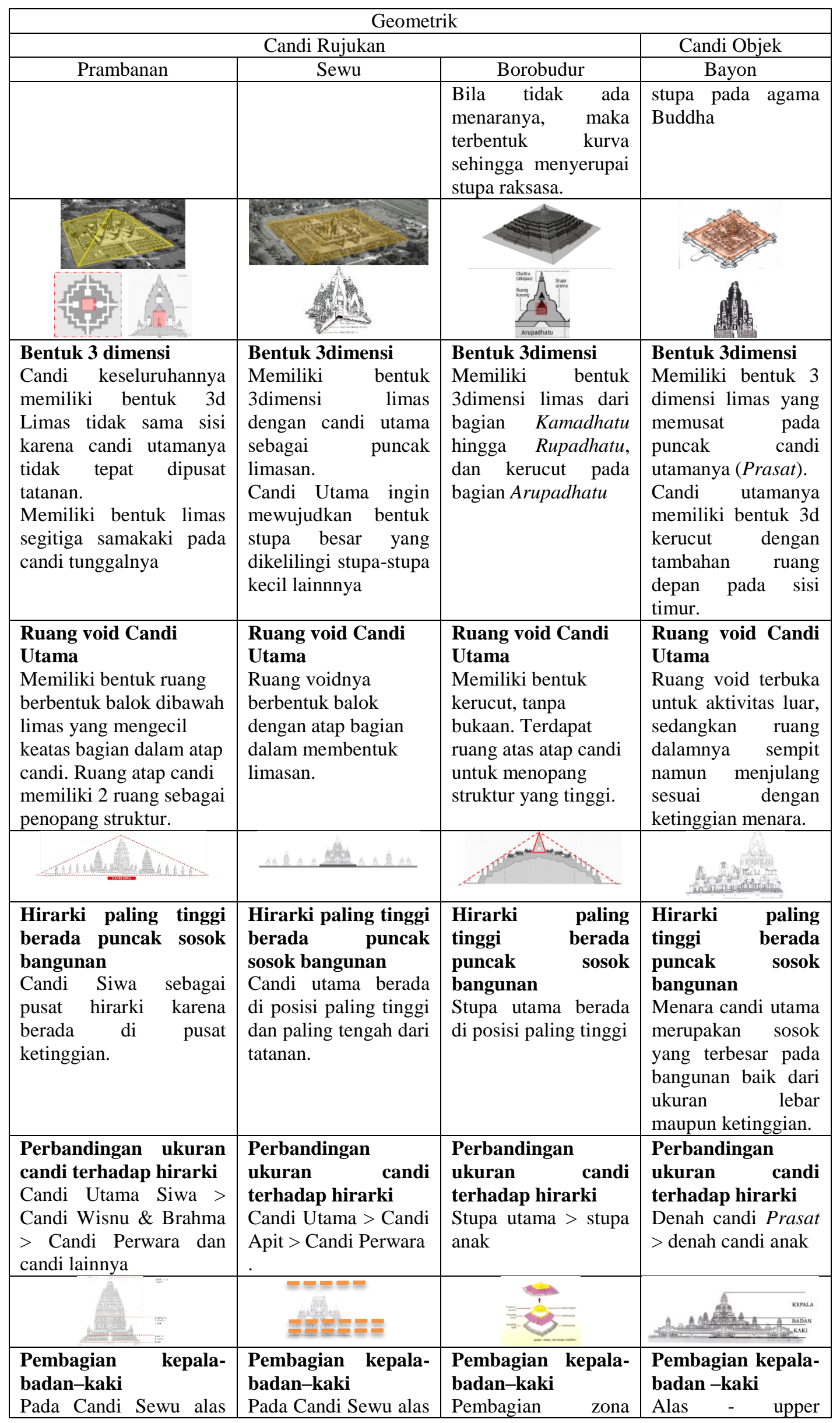




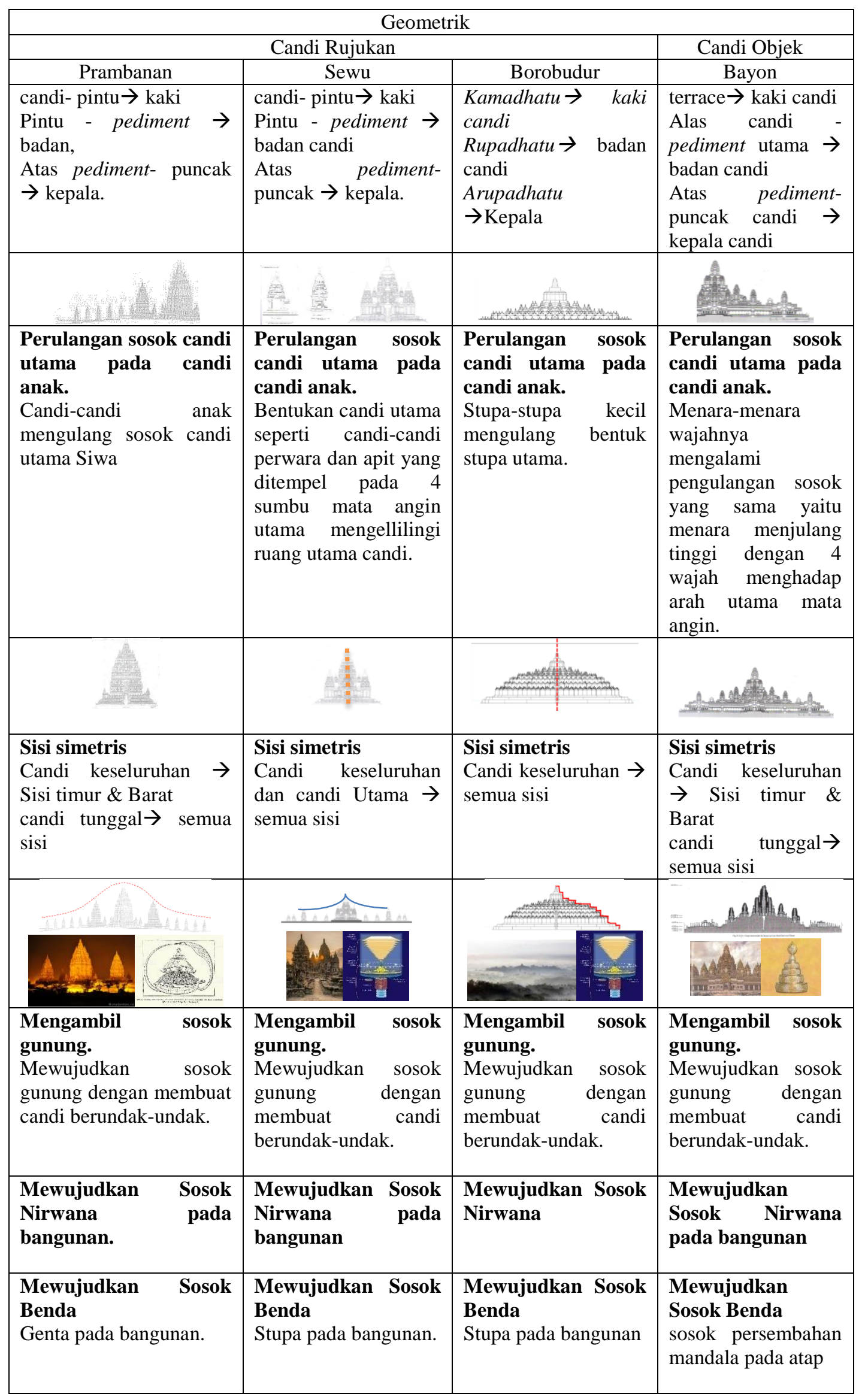




\begin{tabular}{|c|c|c|c|}
\hline \multicolumn{4}{|c|}{ Geometrik } \\
\hline \multicolumn{3}{|c|}{ Candi Rujukan } & Candi Objek \\
\hline Prambanan & Sewu & Borobudur & Bayon \\
\hline $\begin{array}{ll}\text { Bentuk } & \text { pola } \\
\text { permukaan fasad } \\
\text { Terbentuk } \\
\text { pembayangan oleh maju } \\
\text { mundur fasad }\end{array}$ & $\begin{array}{l}\text { Terbentuk pola } \\
\text { permukaan fasad. } \\
\text { Terbentuk pola wajah } \\
\text { apabila darahkan } \\
\text { cahaya dari bawah }\end{array}$ & $\begin{array}{l}\text { Bentuk pola } \\
\text { permukaan fasad } \\
\text { Terbentuk pola } \\
\text { pembayangan oleh } \\
\text { maju mundur fasad. }\end{array}$ & $\begin{array}{l}\text { Bentuk pola } \\
\text { permukaan fasad } \\
\text { Terbentuk pola } \\
\text { pembayangan oleh } \\
\text { maju mundur fasad }\end{array}$ \\
\hline 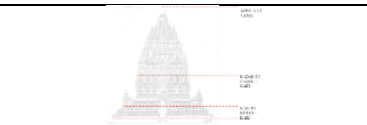 & 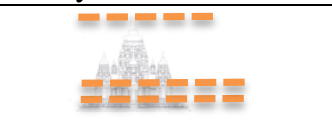 & & 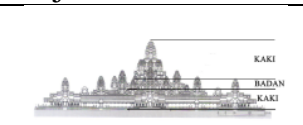 \\
\hline $\begin{array}{c}\text { Proporsi Kepala Badan } \\
\text { Kaki } \\
\text { Badan }+ \text { kaki candi }=1 / 2 \\
\text { seluruh bagian } . \\
\text { Kaki }=1 / 3 \text { (badan+kaki) }\end{array}$ & $\begin{array}{c}\text { Proporsi Kepala } \\
\text { Badan Kaki } \\
\text { Badan + kaki } \\
\text { candi }=1 / 2 \text { seluruh } \\
\text { bagian } . \\
\text { Kaki }=1 / 3 \\
\text { (badan+kaki) }\end{array}$ & $\begin{array}{c}\text { Proporsi Kepala } \\
\text { Badan Kaki } \\
\text { Badan }+ \text { kaki } \\
\text { candi }=1 / 2 \text { seluruh } \\
\text { bagian } . \\
\text { Kaki }=1 / 3 \\
\text { (badan+kaki) }\end{array}$ & $\begin{array}{l}\text { Proporsi Kepala } \\
\text { Badan Kaki } \\
\text { Badan+kaki candi = } \\
\text { kepala candi }\end{array}$ \\
\hline
\end{tabular}

\subsection{ORNAMEN}

Komparasi ornamen diklasifikasi berdasarkan ragam hias yan ada pada candi rujukan untuk kemudian dikomparasi denga yang ada pada candi Bayon.

Tabel 4. Komparasi Ornamen

Sumber gambar: Tim penelitian riset Dikti 2017 Arsitektur, Pusat Studi Angkor, Balai Penelitian Borobudur, dan Balai Pemugaran Cagar Budaya Yogyakarta; dengan modifikasi penulis

\begin{tabular}{|c|c|c|c|}
\hline \multicolumn{4}{|c|}{ Ornamentasi } \\
\hline \multicolumn{3}{|c|}{ Candi Rujukan } & Candi Objek \\
\hline Prambanan & Sewu & Borobudur & Bayon \\
\hline $3+5 / \sin 3$ & & $\mathrm{P}^{\mathrm{n}}$ & \\
\hline $\begin{array}{c}\text { Purnakalasa } \\
\text { Posisi: bawah badan } \\
\text { candi }\end{array}$ & $\begin{array}{c}\text { Purnakalasa } \\
\text { Posisi: relung tngah } \\
\text { ruang } 4 \text { kardinal mata } \\
\text { angin. }\end{array}$ & $\begin{array}{c}\text { Purnakalasa } \\
\text { Posisi: Dinding badan } \\
\text { candi (atas), Railing ( } \\
\text { bawah) }\end{array}$ & $\begin{array}{c}\text { Purnakalasa } \\
\text { Posisi: ukiran Pilaster }\end{array}$ \\
\hline $\begin{array}{l}\text { Relief Dewata } \\
\text { Posisi: Railing }\end{array}$ & $\begin{array}{c}\text { Relief Dewata } \\
\text { Posisi: Dinding candi } \\
\text { Perwara } \\
\end{array}$ & & $\begin{array}{l}\text { Dewata perempuan } \\
\text { posisi: sebelah pintu } \\
\text { gerbang }\end{array}$ \\
\hline 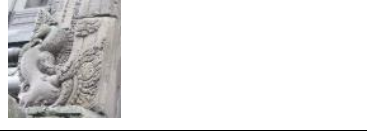 & & & 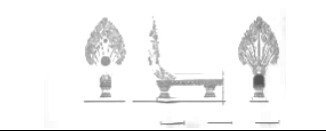 \\
\hline $\begin{array}{l}\text { Makara samping pintu } \\
\text { Posisi: sebelah pintu } \\
\text { gerbang. }\end{array}$ & $\begin{array}{l}\text { Makara samping } \\
\text { pintu } \\
\text { Posisi: sebelah pintu } \\
\text { gerbang. }\end{array}$ & $\begin{array}{l}\text { Makara samping } \\
\text { Gerbang } \\
\text { Posisi: memanjang } \\
\text { dari relung } \\
\text { sebelah pintu } \\
\text { gerbang. }\end{array}$ & $\begin{array}{c}\text { Ornamen ular naga } \\
\text { kepala } 7 \text { keluar dari } \\
\text { mulut makara } \\
\text { Posisi: pediment } \\
\text { Memanhang dari } \\
\text { relung pediment. }\end{array}$ \\
\hline
\end{tabular}




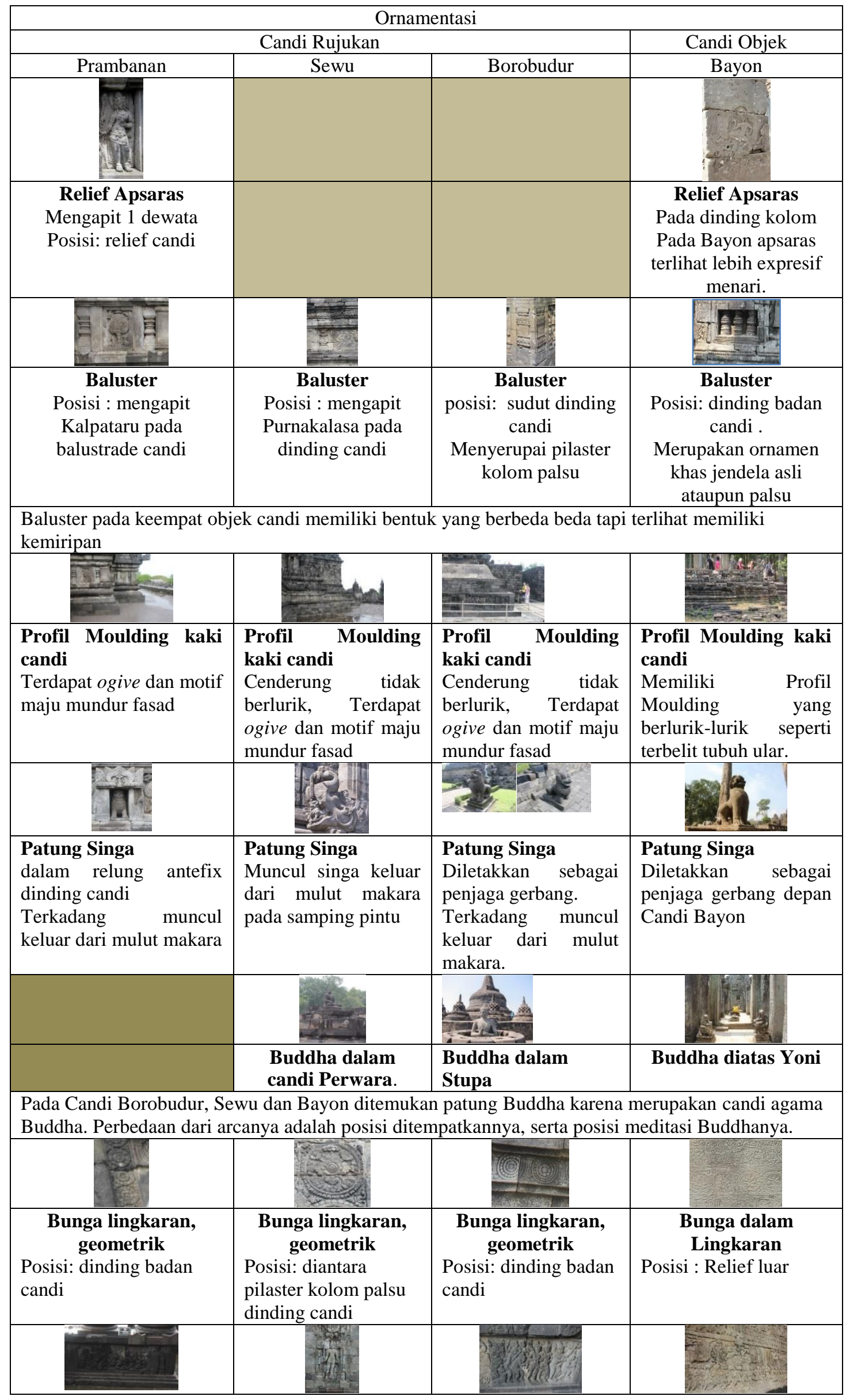




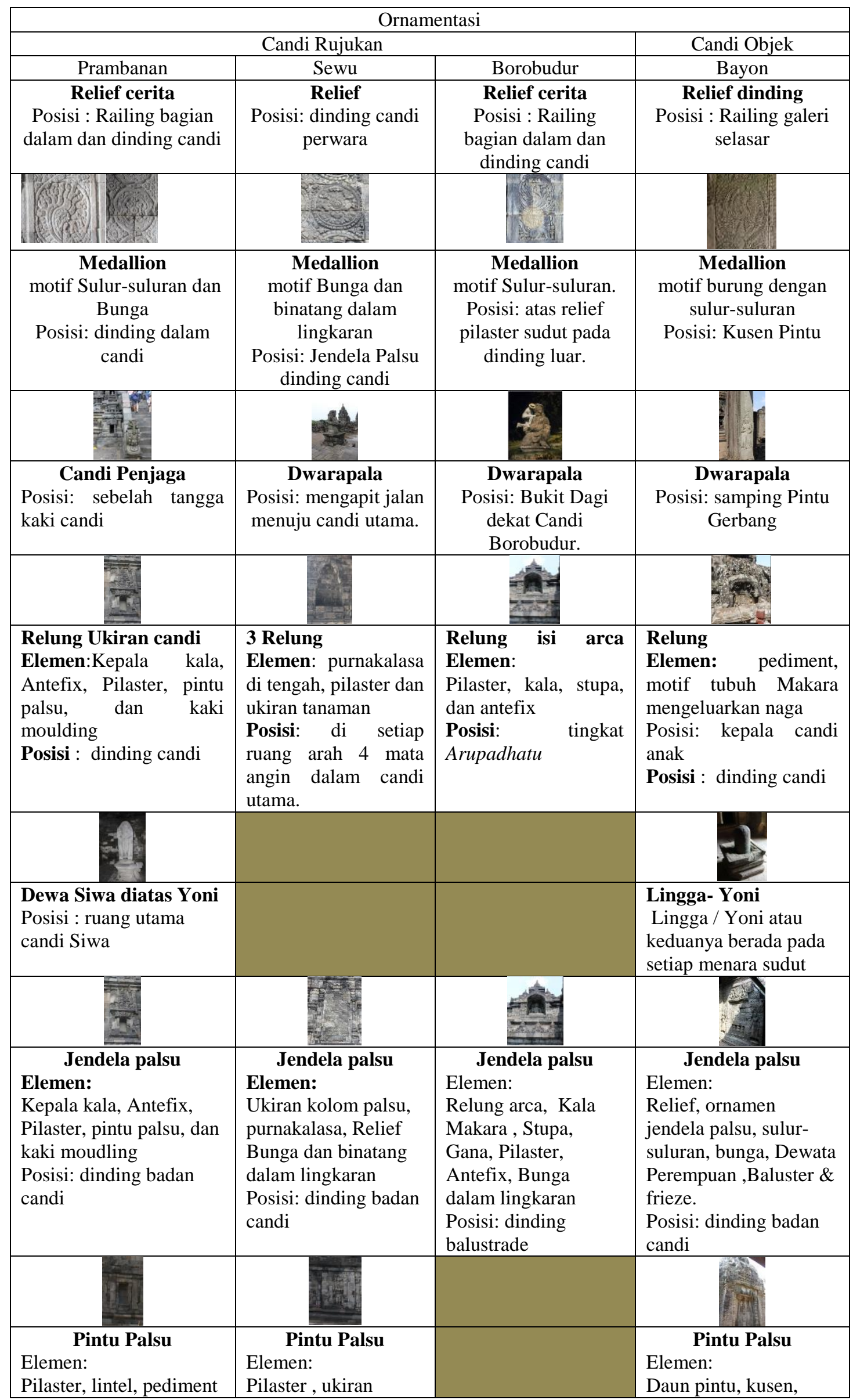




\begin{tabular}{|c|c|c|c|}
\hline \multicolumn{4}{|c|}{ Ornamentasi } \\
\hline \multicolumn{3}{|c|}{ Candi Rujukan } & Candi Objek \\
\hline Prambanan & Sewu & Borobudur & Bayon \\
\hline berupa antefix & dewata, lintel & & $\begin{array}{l}\text { Collonette, Pilaster, } \\
\text { Lintel, dan Pediment }\end{array}$ \\
\hline $\begin{array}{l}\text { Kepala kala, Sulur- } \\
\text { suluran } \\
\text { Posisi : Lintel gerbang, } \\
\text { Jendela palsu, lidah } \\
\text { tangga }\end{array}$ & $\begin{array}{c}\text { Kepala kala } \\
\text { Posisi : Atas relung } \\
\text { pintu dan jendela } \\
\text { palsu }\end{array}$ & $\begin{array}{c}\text { Kepala kala } \\
\text { Posisi : Lintel, } \\
\text { relung, lidah tangga }\end{array}$ & $\begin{array}{c}\text { Kepala kala, Sulur- } \\
\text { suluran } \\
\text { Posisi : Lintel (tidak } \\
\text { pada semua lintel) }\end{array}$ \\
\hline $\begin{array}{l}\text { Lidah tangga berupa } \\
\text { Makara dengan singa } \\
\text { dimulutnya sebagai } \\
\text { lidah Kala } \\
\text { Posisi: sebelah tangga }\end{array}$ & $\begin{array}{lr}\text { Lidah } & \text { tangga } \\
\text { berupa Makara } & \text { Makara } \\
\text { dengan manusia / } \\
\text { singa dimulutnya } \\
\text { Posisi: sebelah tangga }\end{array}$ & $\begin{array}{l}\text { Lidah kala } \\
\text { Posisi: lidah tangga }\end{array}$ & $\begin{array}{l}\text { Lidah balustrade } \\
\text { bentuk makara } \\
\text { Posisi: Upper terrace }\end{array}$ \\
\hline - in- & & & \\
\hline $\begin{array}{c}\text { Antefix } \\
\text { Cenderung berbentuk } \\
\text { mahkota bermotif sulur- } \\
\text { suluran } \\
\text { Posisi: railing, atap } \\
\text { candi }\end{array}$ & $\begin{array}{c}\text { Antefix } \\
\text { Cenderung berbentuk } \\
\text { mahkota bermotif } \\
\text { sulur-suluran } \\
\text { Posisi: Atap candi }\end{array}$ & $\begin{array}{l}\text { Antefix } \\
\text { Cenderung berbentuk } \\
\text { mahkota bermotif } \\
\text { sulur-suluran } \\
\text { Posisi: railing, dan } \\
\text { relung } \\
\end{array}$ & $\begin{array}{c}\text { Antefix } \\
\text { Cenderung berbentuk } \\
\text { seperti pediment pintu } \\
\text { gerbang. } \\
\text { Posisi: atap selasar }\end{array}$ \\
\hline $\begin{array}{l}\text { Kala sudut } \\
\text { Posisi: badan candi dan } \\
\text { railing }\end{array}$ & & $\begin{array}{l}\text { Kala sudut sebagai } \\
\text { jaladwara } \\
\text { Posisi: badan candi }\end{array}$ & $\begin{array}{c}\text { Kala sudut } \\
\text { Posisi: badan candi }\end{array}$ \\
\hline $\begin{array}{l}\text { Jaladwara bentuk } \\
\text { makara }\end{array}$ & $\begin{array}{c}\text { Jaladwara bentuk } \\
\text { makara }\end{array}$ & $\begin{array}{l}\text { Jaladwara bentuk } \\
\text { makara ditopang } \\
\text { gana, Jaladwara } \\
\text { bentuk antefix. }\end{array}$ & $\begin{array}{l}\text { Hanya terdapat salluran } \\
\text { air tanpa jaladwara }\end{array}$ \\
\hline $\begin{array}{c}\text { Hiasan Sulur-suluran } \\
\text { Posisi: ukiran lidah } \\
\text { tangga }\end{array}$ & $\begin{array}{c}\text { Hiasan Sulur- } \\
\text { suluran } \\
\text { Posisi: diantara relief } \\
\text { pilaster }\end{array}$ & $\begin{array}{c}\text { Hiasan Sulur- } \\
\text { suluran } \\
\text { Posisi: diantara relief } \\
\text { pilaster }\end{array}$ & $\begin{array}{l}\text { Hiasan Sulur-suluran } \\
\text { Posisi: pilaster }\end{array}$ \\
\hline 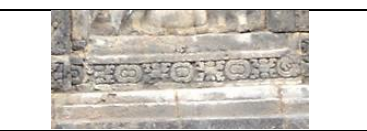 & veles & $\frac{1}{4 x+5}$ & 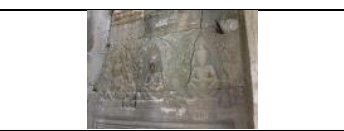 \\
\hline Frieze & Frieze & $\begin{array}{l}\text { Frieze } \\
\text { repetisi }\end{array}$ & $\begin{array}{l}\text { Frieze figure meditasi } \\
\text { berulang. }\end{array}$ \\
\hline $\begin{array}{l}\text { Frieze merupakan moti } \\
\text { secara horizontal mal }\end{array}$ & koratif berulang. Pac & eempat candi ditemu & $\begin{array}{l}\text { banyak pola berulang } \\
\text { asing-masing candi. }\end{array}$ \\
\hline
\end{tabular}




\begin{tabular}{|c|c|c|c|}
\hline \multicolumn{4}{|c|}{ Ornamentasi } \\
\hline \multicolumn{3}{|c|}{ Candi Rujukan } & Candi Objek \\
\hline Prambanan & Sewu & Borobudur & Bayon \\
\hline 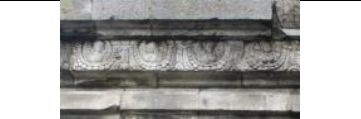 & 7 & & \\
\hline $\begin{array}{l}\text { Guirlande motif } \\
\text { manusia burung. } \\
\text { Posisi: balustrade }\end{array}$ & $\begin{array}{l}\text { Guirlande Motif } \\
\text { Bunga } \\
\text { Posisi: balustrade }\end{array}$ & $\begin{array}{l}\text { Guirlande Motif } \\
\text { Bunga } \\
\text { Posisi: balustrade }\end{array}$ & $\begin{array}{l}\text { Guirlande motif floral } \\
\text { Posisi: balok candi }\end{array}$ \\
\hline $\begin{array}{l}\text { Relief Gana menopang } \\
\text { makara Posisi: kolom } \\
\text { palsu candi utama }\end{array}$ & $\begin{array}{l}\text { Relief Gana } \\
\text { Posisi: atas kolom } \\
\text { plasu candi } \\
\text { menopang atap }\end{array}$ & $\begin{array}{l}\text { Relief Gana } \\
\text { Posisi: atas kolom } \\
\text { palsu candi } \\
\text { menopang atap dan } \\
\text { Jaladwara. }\end{array}$ & $\begin{array}{l}\text { Atlantes } \\
\text { Posisi: Atas kolom }\end{array}$ \\
\hline $\begin{array}{c}\text { Kala-Makara: Makara } \\
\text { Keluar dari mulut } \\
\text { monster } \\
\text { Posisi : Lidah tangga } \\
\end{array}$ & $\begin{array}{l}\text { Makara dengan } \\
\text { manusia / singa } \\
\text { dimulutnya } \\
\text { Posisi: sebelah tangga }\end{array}$ & $\begin{array}{l}\text { Kala-Makara: } \\
\text { Makara Keluar dari } \\
\text { mulut monster } \\
\text { Posisi : Lidah tangga }\end{array}$ & $\begin{array}{l}\text { Ornamen ular naga } \\
\text { keluar dari mulut } \\
\text { makara } \\
\text { Posisi: pediment }\end{array}$ \\
\hline & \begin{tabular}{l}
\multicolumn{1}{c}{ Stupa } \\
Posisi: atap dan \\
railing
\end{tabular} & $\begin{array}{c}\text { Stupa } \\
\text { Posisi: Kepala candi } \\
\text { (stupa utama dan } \\
\text { stupa anak) dan } \\
\text { railing }\end{array}$ & $\begin{array}{c}\text { Hiasan Persembahan } \\
\text { mandala sebagai } \\
\text { ujung atap }\end{array}$ \\
\hline \multicolumn{4}{|c|}{ Stupa hanya ditemukan ada candi yang menganut agama Buddha. } \\
\hline $\begin{array}{l}\text { Arca Garuda } \\
\text { Posisi: candi Wahana } \\
\text { Garuda. }\end{array}$ & \multicolumn{2}{|c|}{$\begin{array}{l}\text { Pada Candi Borobudur dan sewu tidak } \\
\text { ditemukan arca Garuda karena bukan } \\
\text { merupakan candi agama Hindu. }\end{array}$} & $\begin{array}{c}\text { Arca Garuda } \\
\text { Posisi: atap candi } \\
\text { utama. } \\
\end{array}$ \\
\hline
\end{tabular}

\subsection{TABEL CHECKLIST KOMPARASI}

\section{Komparasi Tata Massa}

Tabel 5. Checklist Komparasi Tata Massa

\begin{tabular}{|c|c|c|c|c|c|c|c|c|c|c|}
\hline \multicolumn{11}{|c|}{ Tata Massa } \\
\hline \multirow[t]{2}{*}{ No } & \multirow[t]{2}{*}{ Aspek Unsur Tata Massa Candi } & \multicolumn{3}{|c|}{$\mathrm{P} \rightarrow \mathrm{Byn}$} & \multicolumn{3}{|c|}{$\mathrm{S} \rightarrow$ Byn } & \multicolumn{3}{|c|}{$\mathrm{B} \rightarrow \mathrm{Byn}$} \\
\hline & & TA & TS & $\mathrm{S}$ & TA & TS & $\mathrm{S}$ & TA & TS & $\mathrm{S}$ \\
\hline \multirow[t]{3}{*}{4.1 .1} & Geometri & & & & & & & & & \\
\hline & Bentuk Dasar Tapak & & & $\mathrm{X}$ & & $\mathrm{X}$ & & & & $\mathrm{X}$ \\
\hline & Penggabungan Geometri tapak & & $\mathrm{X}$ & & & $\mathrm{X}$ & & & $\mathrm{X}$ & \\
\hline \multirow[t]{3}{*}{4.1 .2} & Solid -Void Cluster & & & & & & & & & \\
\hline & Koridor yang dibentuk tatanan solid massa & & $\mathrm{X}$ & & & & $\mathrm{X}$ & & $\mathrm{X}$ & \\
\hline & Area void (massa renggang). & & & $\mathrm{X}$ & & & $\mathrm{X}$ & & & $\mathrm{X}$ \\
\hline 4.1 .3 & Hirarki dan Pembagian Tiga & & & & & & & & & \\
\hline
\end{tabular}




\begin{tabular}{|c|c|c|c|c|c|c|c|c|c|c|}
\hline \multicolumn{11}{|c|}{ Tata Massa } \\
\hline \multirow[t]{4}{*}{ No } & \multirow{2}{*}{ Aspek Unsur Tata Massa Candi } & \multicolumn{3}{|c|}{$\mathrm{P} \rightarrow \mathrm{Byn}$} & \multicolumn{3}{|c|}{$\mathrm{S} \rightarrow \mathrm{Byn}$} & \multicolumn{3}{|c|}{ B $\rightarrow$ Byn } \\
\hline & & TA & TS & $\mathrm{S}$ & TA & TS & $\mathrm{S}$ & TA & TS & $\mathrm{S}$ \\
\hline & $\begin{array}{c}\text { Jumlah } 3 \text { Hirarki pada Tapak (dibaca melalui } \\
\text { undakan \& gerbang) }\end{array}$ & & & $\mathrm{X}$ & & & $\mathrm{X}$ & & & $\mathrm{X}$ \\
\hline & $\begin{array}{l}\text { Pemusatan Hirarki (semakin pusat semakin } \\
\text { suci) }\end{array}$ & & $\mathrm{X}$ & & & & $\mathrm{X}$ & & & $\mathrm{X}$ \\
\hline \multirow[t]{2}{*}{4.1 .4} & Irama & & & & & & & & & \\
\hline & Perulangan bentuk dasar geometrik & & $\mathrm{X}$ & & & $\mathrm{X}$ & & & $\mathrm{X}$ & \\
\hline \multirow[t]{2}{*}{4.1 .5} & Simetri & & & & & & & & & \\
\hline & Sisi Simetri & & & $\mathrm{X}$ & & $\mathrm{X}$ & & & $\mathrm{X}$ & \\
\hline \multirow[t]{2}{*}{4.1 .6} & Mandala & & & & & & & & & \\
\hline & $\begin{array}{c}\text { Penerapan konsep mandala pada tatanan } \\
\text { massa }\end{array}$ & & $\mathrm{X}$ & & & & $\mathrm{X}$ & & & $\mathrm{X}$ \\
\hline \multirow[t]{4}{*}{4.1 .7} & Axis & & & & & & & & & \\
\hline & Axis Memusat & & $\mathrm{X}$ & & & & $\mathrm{X}$ & & & $\mathrm{X}$ \\
\hline & Axis Linier & & $\mathrm{X}$ & & & $\mathrm{X}$ & & & $\mathrm{X}$ & \\
\hline & TOTAL & 0 & 7 & 4 & 0 & 5 & 6 & 0 & 5 & 6 \\
\hline & $\begin{array}{r}\text { Keterangan : } \mathrm{P}=\text { Prambanan, } \mathrm{S}=\text { Sewu } \\
\text { TA }=\text { Tidak Ada TS=Tidak }\end{array}$ & $\begin{array}{l}=\mathrm{B} \\
\text { erup }\end{array}$ & $\mathrm{S}=\mathrm{S}$ & & & & & & & \\
\hline
\end{tabular}

\section{Komparasi Denah}

Tabel 6. Checklist Komparasi Denah

\begin{tabular}{|c|c|c|c|c|c|c|c|c|c|c|}
\hline \multicolumn{11}{|c|}{ Denah } \\
\hline \multirow[t]{2}{*}{ No } & \multirow[t]{2}{*}{ Aspek Unsur Denah Candi } & \multicolumn{3}{|c|}{$\mathrm{P} \rightarrow \mathrm{Byn}$} & \multicolumn{3}{|c|}{$\mathrm{S} \rightarrow$ Byn } & \multicolumn{3}{|c|}{ B $\rightarrow$ Byn } \\
\hline & & TA & TS & $\mathrm{S}$ & TA & TS & $\mathrm{S}$ & TA & TS & $\mathrm{S}$ \\
\hline \multirow[t]{3}{*}{4.2 .1} & Geometri & & & & & & & & & \\
\hline & Bentuk Dasar Denah. & & $\mathrm{X}$ & & & $\mathrm{X}$ & & & $\mathrm{X}$ & \\
\hline & Penggabungan Geometri Denah & & $\mathrm{X}$ & & & $\mathrm{X}$ & & & & $\mathrm{X}$ \\
\hline \multirow[t]{3}{*}{4.2 .2} & Volumetri & & & & & & & & & \\
\hline & Area Aktivitas. & & $\mathrm{X}$ & & & $\mathrm{X}$ & & $\mathrm{X}$ & & \\
\hline & Ruang void Candi Utama (Prasat) & & $\mathrm{X}$ & & & $\mathrm{X}$ & & & $\mathrm{X}$ & \\
\hline \multirow[t]{3}{*}{4.2 .3} & Hirarki & & & & & & & & & \\
\hline & Perbandingan ukuran candi terhadap hirarki. & & & $\mathrm{X}$ & & & $\mathrm{X}$ & & & $\mathrm{X}$ \\
\hline & Pemusatan Hirarki (semakin pusat semakin suci) & & & $\mathrm{X}$ & & & $\mathrm{X}$ & & $\mathrm{X}$ & \\
\hline \multirow[t]{2}{*}{4.2 .4} & Irama & & & & & & & & & \\
\hline & Perulangan bentuk denah & & $\mathrm{X}$ & & & $\mathrm{X}$ & & & $\mathrm{X}$ & \\
\hline \multirow[t]{2}{*}{4.2 .5} & Simetri & & & & & & & & & \\
\hline & Sisi Simetri & & $\mathrm{X}$ & & & $\mathrm{X}$ & & & $\mathrm{X}$ & \\
\hline \multirow[t]{2}{*}{4.2 .6} & Mimesis & & & & & & & & & \\
\hline & Penerapan Bentuk Denah & & $\mathrm{X}$ & & & & $\mathrm{X}$ & & $\mathrm{X}$ & \\
\hline \multirow[t]{3}{*}{4.2 .7} & Axis & & & & & & & & & \\
\hline & Tipe Axis & & $\mathrm{X}$ & & & $\mathrm{X}$ & & & $\mathrm{X}$ & \\
\hline & TOTAL & 0 & 8 & 2 & 0 & 7 & 3 & 1 & 7 & 2 \\
\hline & $\begin{array}{r}\text { Keterangan : } \mathrm{P}=\text { Prambanan, } \mathrm{S}=\text { Sewu, } \\
\text { TA }=\text { Tidak Ada } \mathrm{TS}=\text { Tidak }\end{array}$ & $\begin{array}{l}3=\mathrm{BC} \\
\text { erup }\end{array}$ & $\mathrm{S}=$ & & & yon & & & & \\
\hline
\end{tabular}




\section{Komparasi Sosok}

Tabel 7. Checklist Komparasi Sosok

\begin{tabular}{|c|c|c|c|c|c|c|c|c|c|c|}
\hline \multicolumn{11}{|c|}{ Sosok } \\
\hline \multirow[t]{2}{*}{ No } & \multirow[t]{2}{*}{ Aspek Unsur Sosok Candi } & \multicolumn{3}{|c|}{$\mathrm{P} \rightarrow \mathrm{Byn}$} & \multicolumn{3}{|c|}{$\mathrm{S} \rightarrow \mathrm{Byn}$} & \multicolumn{3}{|c|}{ B $\rightarrow$ Byn } \\
\hline & & TA & $\mathrm{TS}$ & $\mathrm{S}$ & TA & TS & $\mathrm{S}$ & TA & TS & $\mathrm{S}$ \\
\hline \multirow[t]{2}{*}{4.3 .1} & Geometri & & & & & & & & & \\
\hline & Keserupaan dengan bentuk dasar & & $\mathrm{X}$ & & & & $\mathrm{X}$ & & $\mathrm{X}$ & \\
\hline \multirow[t]{3}{*}{4.3 .2} & Volumetri & & & & & & & & & \\
\hline & Bentuk 3dimensi & & & $\mathrm{X}$ & & $\mathrm{X}$ & & & $\mathrm{X}$ & \\
\hline & Ruang void Candi Utama & & $\mathrm{X}$ & & & $\mathrm{X}$ & & & $\mathrm{X}$ & \\
\hline \multirow[t]{3}{*}{4.3 .3} & Hirarki & & & & & & & & & \\
\hline & $\begin{array}{c}\text { Hirarki paling tinggi berada puncak sosok } \\
\text { bangunan }\end{array}$ & & $\mathrm{X}$ & & & $\mathrm{X}$ & & & & $\mathrm{X}$ \\
\hline & Perbandingan ukuran candi terhadap hirarki & & & $\mathrm{X}$ & & & $\mathrm{X}$ & & & $\mathrm{X}$ \\
\hline \multirow[t]{2}{*}{4.3 .4} & Pembagian Tiga & & & & & & & & & \\
\hline & Pembagian kepala-badan -kaki & & $\mathrm{X}$ & & & $\mathrm{X}$ & & & $\mathrm{X}$ & \\
\hline \multirow[t]{2}{*}{4.3 .5} & Irama & & & & & & & & & \\
\hline & $\begin{array}{c}\text { Perulangan sosok candi utama pada candi } \\
\text { anak. }\end{array}$ & & $\mathrm{X}$ & & & & $\mathrm{X}$ & & $\mathrm{X}$ & \\
\hline \multirow[t]{2}{*}{4.3 .6} & Simetri & & & & & & & & & \\
\hline & Sisi simetris & & & $\mathrm{X}$ & & $\mathrm{X}$ & & & $\mathrm{X}$ & \\
\hline \multirow[t]{4}{*}{4.3 .7} & Mimesis & & & & & & & & & \\
\hline & Mengambil sosok gunung. & & $\mathrm{X}$ & & & $\mathrm{X}$ & & & & $\mathrm{X}$ \\
\hline & Mewujudkan Sosok Nirwana pada bangunan. & & $\mathrm{X}$ & & & $\mathrm{X}$ & & & $\mathrm{X}$ & \\
\hline & Mewujudkan Sosok Benda & & $\mathrm{X}$ & & & $\mathrm{X}$ & & & $\mathrm{X}$ & \\
\hline \multirow[t]{2}{*}{4.3 .8} & Tekstur / Gelap Terang & & & & & & & & & \\
\hline & Bentuk pola permukaan fasad & & $\mathrm{X}$ & & & $\mathrm{X}$ & & & $\mathrm{X}$ & \\
\hline \multirow[t]{3}{*}{4.3 .9} & Proporsi dan skala & & & & & & & & & \\
\hline & Proporsi Kepala Badan Kaki & & $\mathrm{X}$ & & & $\mathrm{X}$ & & & $\mathrm{X}$ & \\
\hline & TOTAL & 0 & 10 & 3 & 0 & 10 & 3 & 0 & 10 & 3 \\
\hline & $\begin{array}{r}\text { Keterangan : } \mathrm{P}=\text { Prambanan, } \mathrm{S}=\mathrm{Sew} \\
\text { TA=Tidak Ada } \mathrm{TS}=\text { Tida }\end{array}$ & r ip &, $\mathrm{S}=$ & & $3 y n$ & 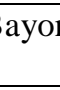 & & & & \\
\hline
\end{tabular}

\section{Komparasi Ornamen}

Tabel 8. Checklist Komparasi Elemen

\begin{tabular}{|c|c|c|c|c|c|c|c|c|c|}
\hline \multicolumn{10}{|c|}{ Ornamen } \\
\hline \multirow[t]{2}{*}{ Ornamen Candi Bayon } & \multicolumn{3}{|c|}{$\mathrm{P} \rightarrow \mathrm{Byn}$} & \multicolumn{3}{|c|}{$\mathrm{S} \rightarrow$ Byn } & \multicolumn{3}{|c|}{$\mathrm{B} \rightarrow \mathrm{Byn}$} \\
\hline & TA & TS & $\mathrm{S}$ & TA & $\mathrm{TS}$ & $\mathrm{S}$ & TA & TS & $\mathrm{S}$ \\
\hline \multicolumn{10}{|l|}{ Ornamen ular kepala 7} \\
\hline \multicolumn{10}{|l|}{ Ukiran kolom asli } \\
\hline Purnakalasa & & $\mathrm{X}$ & & & $\mathrm{X}$ & & & $\mathrm{X}$ & \\
\hline Dewata & & $\mathrm{X}$ & & & $\mathrm{X}$ & & & & \\
\hline Makara & & $\mathrm{X}$ & & & $\mathrm{X}$ & & & $\mathrm{X}$ & \\
\hline Apsaras & & $\mathrm{X}$ & & & & & & & \\
\hline Baluster & & $\mathrm{X}$ & & & $\mathrm{X}$ & & & $\mathrm{X}$ & \\
\hline Moulding & & $\mathrm{X}$ & & & $\mathrm{X}$ & & & $\mathrm{X}$ & \\
\hline Arca Singa & & $\mathrm{X}$ & & & $X$ & & & $\mathrm{X}$ & \\
\hline \multicolumn{10}{|l|}{ Ukiran pada balok } \\
\hline Bunga dalam lingkaran & & $\mathrm{X}$ & & & $\mathrm{X}$ & & & $\mathrm{X}$ & \\
\hline Relief cerita & & $\mathrm{X}$ & & & $\mathrm{X}$ & & & $\mathrm{X}$ & \\
\hline Medallion & & $\mathrm{X}$ & & & $\mathrm{X}$ & & & $\mathrm{X}$ & \\
\hline Dwarapala & & & & & $\mathrm{X}$ & & & $\mathrm{X}$ & \\
\hline Relung & & $\mathrm{X}$ & & & $\mathrm{X}$ & & & $\mathrm{X}$ & \\
\hline
\end{tabular}




\begin{tabular}{|c|c|c|c|c|c|c|c|c|c|}
\hline \multicolumn{10}{|c|}{ Ornamen } \\
\hline \multirow[t]{2}{*}{ Ornamen Candi Bayon } & \multicolumn{3}{|c|}{$\mathrm{P} \rightarrow \mathrm{Byn}$} & \multicolumn{3}{|c|}{$\mathrm{S} \rightarrow \mathrm{Byn}$} & \multicolumn{3}{|c|}{$\mathrm{B} \rightarrow \mathrm{Byn}$} \\
\hline & TA & TS & $\mathrm{S}$ & TA & TS & $\mathrm{S}$ & TA & TS & $\mathrm{S}$ \\
\hline Lingga- Yoni & & $\mathrm{X}$ & & & & & & & \\
\hline Jendela Palsu & & $\mathrm{X}$ & & & $\mathrm{X}$ & & & $\mathrm{X}$ & \\
\hline Pintu Palsu & & $\mathrm{X}$ & & & $\mathrm{X}$ & & & & \\
\hline Kepala kala & & $\mathrm{X}$ & & & $\mathrm{X}$ & & & $\mathrm{X}$ & \\
\hline Lidah tangga & $\mathrm{X}$ & & & $\mathrm{X}$ & & & $\mathrm{X}$ & & \\
\hline Antefix & & $\mathrm{X}$ & & & $\mathrm{X}$ & & & $\mathrm{X}$ & \\
\hline Kala sudut & & $\mathrm{X}$ & & & & & & $\mathrm{X}$ & \\
\hline Jaladwara & $\mathrm{X}$ & & & $\mathrm{X}$ & & & $\mathrm{X}$ & & \\
\hline Hiasan Sulur-suluran & & $\mathrm{X}$ & & & $\mathrm{X}$ & & & $\mathrm{X}$ & \\
\hline Frieze & & $\mathrm{X}$ & & & $\mathrm{X}$ & & & $\mathrm{X}$ & \\
\hline Guirlande & & $\mathrm{X}$ & & & $\mathrm{X}$ & & & $\mathrm{X}$ & \\
\hline \multicolumn{10}{|l|}{ Collonette dan kusen pintu. } \\
\hline Gana & & $\mathrm{X}$ & & & $\mathrm{X}$ & & & $\mathrm{X}$ & \\
\hline Kala-Makara & $\mathrm{X}$ & & & $\mathrm{X}$ & & & $\mathrm{X}$ & & \\
\hline \multicolumn{10}{|l|}{$\begin{array}{l}\text { Ornamen ular naga keluar dari mulut } \\
\text { makara }\end{array}$} \\
\hline Ratna & $\mathrm{X}$ & & & & & & & & \\
\hline Keben & $\mathrm{X}$ & & & & & & & & \\
\hline Stupa & & & & & $\mathrm{X}$ & & & $\mathrm{X}$ & \\
\hline Garuda & & $\mathrm{X}$ & & & & & & & \\
\hline \multicolumn{10}{|l|}{ Antefix ular kepala 7} \\
\hline \multicolumn{10}{|c|}{ Pintu Candi } \\
\hline Pilaster & & $\mathrm{X}$ & & & $\mathrm{X}$ & & & $\mathrm{X}$ & \\
\hline Pediment Gerbang masuk & & $\mathrm{X}$ & & & $\mathrm{X}$ & & & $\mathrm{X}$ & \\
\hline Lintel Kepala kala & & $\mathrm{X}$ & & & $\mathrm{X}$ & & & $\mathrm{X}$ & \\
\hline \multicolumn{10}{|c|}{ Ornamen Kepala Candi } \\
\hline Modul ornamen Perspektifis & & $\mathrm{X}$ & & & $\mathrm{X}$ & & & $\mathrm{X}$ & \\
\hline Puncak kepala candi & & $\mathrm{X}$ & & & $\mathrm{X}$ & & & $\mathrm{X}$ & \\
\hline Elemen atap yang tersebar rata & & $\mathrm{X}$ & & & $\mathrm{X}$ & & & $\mathrm{X}$ & \\
\hline Profil Moulding kepala & & $\mathrm{X}$ & & & $\mathrm{X}$ & & & $\mathrm{X}$ & \\
\hline Jendela Palsu pada kepala candi & & $\mathrm{X}$ & & & $\mathrm{X}$ & & & & \\
\hline Rekapitulasi Data & 5 & 30 & 0 & 3 & 28 & 0 & 3 & 26 & 0 \\
\hline
\end{tabular}

\section{KESIMPULAN}

\subsection{KESIMPULAN TATA MASSA}

Ditemukan prinsip yang sama dalam penataan massa Candi Bayon namun mengalami modifikasi sesuai dengan penataan tradisional massa candi Angkor. Pada Candi Bayon ditemukan prinsip elemen penataan massa yang tidak ditemukan pada candi objek pembanding dari Indonesia seperti: Keberadaan unsur air (parit, kolam, dll), dan penataan quincunx pada candi utama

\subsection{KESIMPULAN DENAH}

Ditemukan prinsip yang sama dalam membentuk ruang candi utama yang serupa dengan Prambanan dan Sewu, namun mengalami pengembangan menjadi lebih rumit daripada denah Borobudur, Sewu, dan Prambanan. Pada Candi Bayon ditemukan prinsip pembuatan denah yang tidak ditemukan pada candi objek pembanding dari Indonesia seperti: 
Keberadaan ruang selasar beratap mengelilingi keseluruhan candi, dan ruang perpustakaan yang berada di dekat gerbang pintu masuk utama candi.

\subsection{KESIMPULAN SOSOK}

Ditemukan prinsip yang sama dalam pembentukan sosok Candi Bayon namun mengalami modifikasi sesuai dengan penataan tradisional massa candi Angkor.

Pada Bayon ditemukan sosok yang mirip dengan candi-candi Jawa era Klasik Tengah sebagai objek pembanding, yaitu: (1) Punden berundak-undak berbentuk Piramid $\rightarrow$ Borobudur, (2) Siluet bentuk stupa raksasa pada Prasat Bayon $\rightarrow$ candi utama Borobudur dan Sewu, dan (3) Candi tunggal Bayon $\rightarrow$ Candi Sewu dan Prambanan

\subsection{KESIMPULAN ORNAMEN}

Pada komparasi ornamen ditemukan beberapa elemen ornamen yang sama klasifikasinya namun memiliki sosok yang berbeda baik dari detail maupun ukuran. Perbedaan sosok ornamen dimungkinkan karena adanya pengembangan budaya luar yang masuk dengan menggunakan local genius dan kesesuaian dengan budaya lokal setempat yang dimiliki. Banyak ornamen yang sama secara klasifikasi namun penempatannya berbeda pada Candi Bayon dan candi Indonesia. Terdapat ornamen Bayon yang tidak ditemukan di Jawa, dan terdapat ornamen candi Jawa yang tidak ditemukan di Bayon.

\subsection{KESIMPULAN KESELURUHAN}

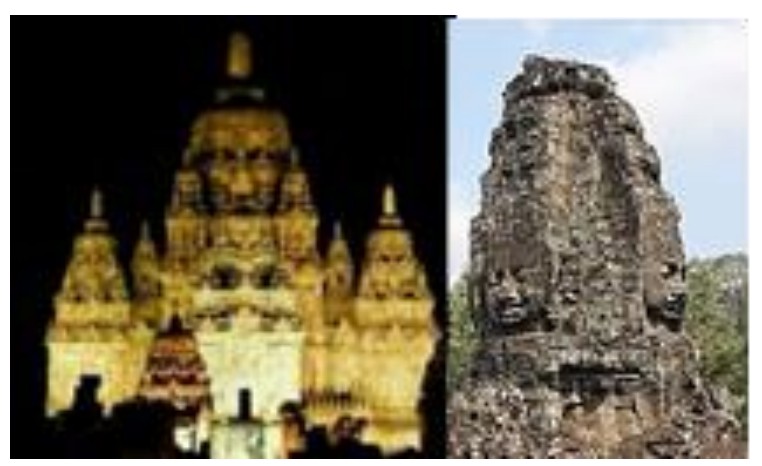

Figur 8. Sosok Sewu-Bayon, bila Candi Sewu diberi pencahayaan dari bawah, terbentuk pola wajah pada menara seperti Bayon

Berdasarkan analisis ditemukan bahwa Candi Bayon memiliki keserupaan paling tinggi dengan Candi Sewu, namun juga memiliki keserupaan yang tinggi juga dengan Candi Borobudur dan Prambanan. Dari keserupaan yang ditemukan pada keempat unsur-unsur tersebut dapat disimpulkan bahwa terdapat indikasi pengaruh Candi Jawa era Klasik Tengah sebagai sumber inspirasi perancangan dan pembuatan Candi Bayon Kamboja. Namun diduga karena Candi Bayon dibangun lama setelah pengaruh Jawa masuk pada era awal pembangunan Kerajaan Angkor, maka yang ditemukan persisten serupa dengan candi Jawa era Klasik Tengah hanyalah prinsip perancangan arsitekturnya saja, sedangkan pada ornamentasi tidak ditemukan elemen yang persis serupa, dimungkinkan karena pengaruh dari negara lain dan pengembangan oleh local genius masyarakat Kamboja. Persistensi penggunaan unsur-unsur candi yang ada di Candi Borobudur, Prambanan, dan Sewu (Candi Jawa era Klasik Tengah) membuktikan bahwa arsitektur candi Jawa era Klasik Tengah Indonesia eksis dan muncul di Kamboja.

Penulis juga menemukan bahwa memang ada pengaruh dari negara lain selain Indonesia pada arsitektur Candi Bayon sehingga dapat dikatakan bahwa Arsitektur candi 
Kamboja bersifat eklektik menggabungkan berbagai gaya arsitektur dan mengembangkannya dengan kejeniusan lokal masyarakat setempat.

Prinsip arsitektur Jawa era Klasik Tengah dipertahankan karena sesuai dengan dasardasar penting arsitektur Kamboja. Penggunaan punden berundak seperti Borobudur dan menara ramping seperti Sewu dan Prambanan diduga karena Bayon belum memiliki teknologi membuat highrise building sehingga mewujudkannya dengan undakan.

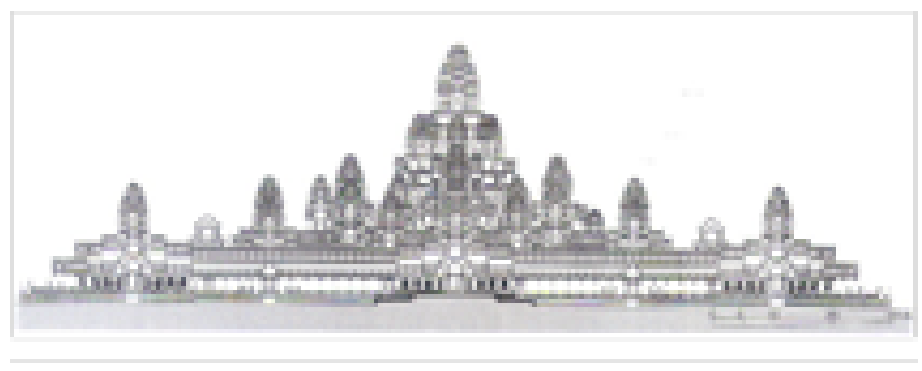

Figur 9. Tampak Candi Bayon

Sumber: De Ta Phrom Au Bayon, 2004

Dugaan lain dibentuknya undakan dan menara juga karena memang ada konsep pembentukan Candi Gunung pada kuil-kuil di Kamboja termasuk Bayon sebagai kuil utama pada era Bayon. Melalui perang, dan pergantian kebudayaan, Candi Bayon mengalami perkembangan dan kemajuan peradaban di berbagai aspek termasuk arsitektur. Terbukti dari ditemukannya teknologi mutakhir pada Bayon meskipun tidak jauh berbeda dari candi-candi Angkor sebelumnya dan candi-candi Indonesia.

\section{DAFTAR PUSTAKA}

Jurnal

Prajudi, Rahadhian, H, 2008, The Architectural Development of Candi in Java, Indonesia, Journal of South East Asia JSEA vol 11, NUS- SingaporeJournal of South East Asia JSEA vol 11, NUS- Singapore

Prajudi, Rahadhian, H, 2014, Kajian Unsur Arsitektonik Transformatif dalam Arsitektur Rumah Tradisional di Indonesia -Puslitbangkim, Lombok

Prajudi, Rahadhian, H 2015, Arsitektur Candi sebagai representasi kuatnya tradisi membangun di Indonesia, Kolokium Dies Natalis Fakutas Teknik, Unpar, Bandung.

\section{Buku}

Booth, Andrew (2016), The Angkor Guidebook, Thailand, Amarin Printing

Chihara, Daigoro (1996), Hindu-Buddhist Architecture in Southeast Asia, New York, E.J. Brill.

Cunin, Oliver, (2007), Bayon, New Perspective, Thailand, River Books.

Degroot, dan Tim (2013), Magical Prambanan, Yogyakarta, BAB Publishing Indonesia

Dumarcay, Jaques (2007), Candi Sewu dan Arsitektur Bangunan Agama Buddha di Jawa Tengah, Jakarta, KPG Petrotchenko, Michel (2012), Focusing on the Angkor Temples: The Guidebook, Bangkok, Paperback.

Jacques, Claude (1999), Angkor, Bonner Cologne, Konemann

Lall, Vikrem (2014), Architecture of The Buddhist World: The Golden Lands, JF Publishing, Malaysia

Ortner, Jon (2002), Angkor, New York, Abbeville Press Publishers

Philippe, Bernard, G (2002), Indocina Persilangan Kebudayaan, Jakarta, Kepustakaan Populer Gramedia

Sahai, Sachchidanand, (2007), The Bayon of Angkor Thom, White Lotus

Snodgrass, Adrian (1984), The Symbolism of The Stupa: Studies on Southeast Asia, New York, SEAP

Tjahjono, Gunawan, editor (2009), Sejarah Kebudayaan Indonesia, Arsitektur, Jakarta, Raja Grafindo Perkasa.

Tesis/Disertasi

Prajudi, Rahadhian, H ,1999, Kajian Tipo-Morfologi Arsitektur Candi di Jawa, Thesis, Arsitektur Institut Teknologi Bandung, Bandung Bandung

2011, Representasi Candi dalam Dinamika Arsitektur di Indonesia, Disertasi Doktor, Unpar,

Soekmono R., 1974, Candi, Fungsi dan Pengertiannya, Disertasi Doktor, Universitas Indonesia, Jakarta 


\section{Skripsi}

Citra, Irwan, 2015, Perkembangan Tatanan Massa dan Ruang Arsitektur Candi di Jawa (Dari Masa Klasik Tua, Klasik Tengah, dan Kilasik Muda), Skripsi Universitas Katolik Parahyangan, Bandung

Halim, Andre, 2016, Makna Ornamen pada Bangunan Candi Hindu dan Buddha di Pulau Jawa ( Era Klasik Tua - Klasik Tengah - Klasik Muda), Skripsi Universitas Katolik Parahyangan, Bandung

Leewan, 2015, Penerapan Konsep Mahayana pada Arsitektur Candi Era Mataram Kuno. Objek Studi: Candi Borobudur, Mendut, Pawon, Kalasan, dan Sewu, Skripsi Universitas Katolik Parahyangan, Bandung

Ramos, 2016, Dinamika Penerapan Proporsi Pada Arsitektur Candi Tipe Menara Era Klasik Tua-Tengah-Muda di Pulau Jawa, Skripsi Universitas Katolik Parahyangan, Bandung. 